
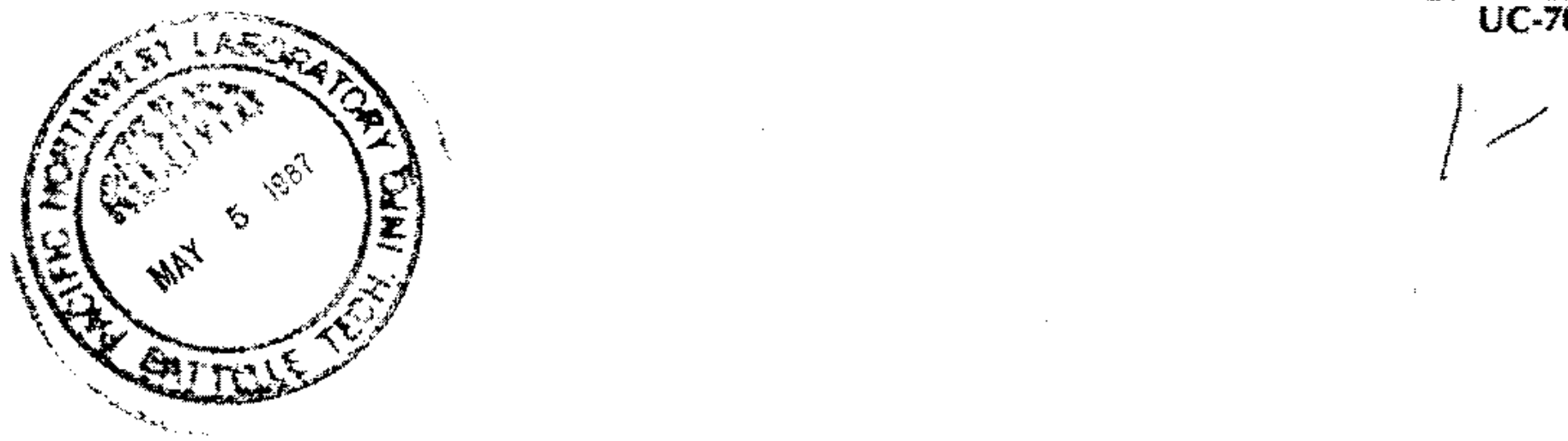

\title{
In Situ Vitrification of Oak Ridge National Laboratory Soil and Limestone
}

\author{
1. G. Carter \\ S. $\mathrm{O}$, Bates \\ C. D. Maupin
}

March 1987

Prepared for the U.S. Department of Energy under Contract DE-AC06-76RLO 1830

Pacific Northwest Laboratory Operated for the U.S. Department of Energy by Battelle Memorial Institute 


\title{
DISCLAMER
}

This tepart was prepared ay an account of work sponsored by an agency of the United States Government. Nather lhe United States Government nor anyzgency thereof, nor Battelie Memorial institute, nor any of theif employes, makes any warranty, expressed or implied, or assumes any legal lizbility or responsibility for the accutacy, completeness, of usefulness of any information, apparatus, product, or process disklosed, ar represents that its use would not infringe privately owned rights, Reterence herein to any specific conmercial product, process, or service by trade name, trademark, manufacturer, or othenwiste, thes not necessarily constitute or inply is endorsement, recommendation, af favoring by the United States Covernment of any agency thereof, or Battelle Atertorial institute. The views and opinions of authors expressed herein do not necessaly state or refiect those of the Unifed Siates Government or any agenoy thereof, or Battelle Memoral Instituie.

\author{
PACIFIC NORTHWEST LABORATORY \\ operated by \\ BATTELLE MEMORIAL INSTITUTE \\ for the \\ UNITED STATES DEPARTMENT OF ENERGY \\ under Contract DE-ACOC-76RLO T830
}

\begin{tabular}{|c|c|}
\hline \multicolumn{2}{|c|}{ 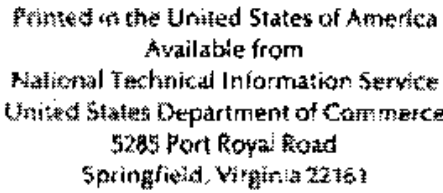 } \\
\hline \multicolumn{2}{|c|}{ 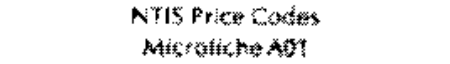 } \\
\hline \multicolumn{2}{|c|}{ frinted fogy } \\
\hline Pazes & $\begin{array}{l}\text { Price } \\
\text { fodes }\end{array}$ \\
\hline (xiz-1253 & $\mathrm{AO} 2$ \\
\hline 026050 & Aas \\
\hline D) & A 14 \\
\hline $07 \%-100$ & $\operatorname{seg}$ \\
\hline $701 \% \times 725$ & Ate \\
\hline 126.150 & A㭋 \\
\hline $151 \times 175$ & Aft \\
\hline $17+200$ & Ang \\
\hline $201+2125$ & स. 010 \\
\hline $224-2 x+5$ & At11: \\
\hline $251 \times 275$ & A012 \\
\hline $27 z-3$ & A013 \\
\hline
\end{tabular}



d. G. Carter
S. 0. Bates
G. D. Maupin

March 198\%

Prepared for

the U.S. Department of Energy

under Contract OE-ACO5-75RLO 1830

Pacific Northwest Laboratory

Richland, Washington 99352 


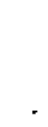




\section{SUMWARY}

Process feasiblitty studies were successfully performed on two different developmental scales to determine the technical appllcation of in situ vitrification (15V) (Ona et al. 1983) to Oak Ridge National Laboratory (ORML) interneditemlevel waste. (a) In the laboratory, testing was performed on crucibles containing quanities of $50 \%$ ORNL soil and $50 \%$ ORNL limestone. In the engineering-scale testing, a 1/12-scaled simulation of brit. Trench 7 was constructed and vitrified, resulting in waste product soil and inestone concentrations of $68 \%$ and $32 \%$, respectively*

Results from the two scales of testing indicate that the ORML intermediate-ievel waste sites may be successfully processed by 15 ; the waste form will retain significant quantities of the cesiun and strontiun Because 137 s is the major component of the radionuclide inventory in the ORN! seepage pits and trenches, final fielo process decontamination fators (i.e., off gas at the ground surface relative to the waste inventory) of $10^{4}$ are desired to minimze activity buildup in the of thas system. These valwes were realized during the engineering-scale test for both cesium and strontium, The vitrified material eftectively contained $99.996 \%$ of the cesium and strontium placed in the englneering-scale test. This is equivalent co decontamination factors of greater than $10^{4}$. Volune reduction for the engunearingscale test was $60 \%$. No migration of the cesium to the uncontaminated surrounding soil was detected. These favorable results indicate that, once verified in a pllot-scale test, an adequately designed ISV systen could be produced to treat the optli. seepage ots and trenches whout excessive activity accumulam tion in the off-gas treatnent system.

(a) Work performed under Contract DE-A006-760L0 1830 for the 1.5 . Department of Energy. 


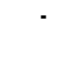




\section{ACKNOWLEDGMENTS}

Pacific Northwest haboratory (PNL) gratefully acknowledges 0ak Ridge National Laboratory (ORNL) for providing the opportunity to perform this feasibility study. We especialiy appreciate the enthusiastic support of Brian Spalding, research staft member of ORNL's Envitronmental Sclences. We would Fike to thank Jim Buelt and Mike Longaker for their technical assistance in test preparation, test operations, and data collection and evaluation.

Frank lara and their respect ive sifafs were invaluable in providing highquality laboratary studies and analycical services to the program. 



\section{CONTENTS}

SUMMARY $\ldots \ldots \ldots \ldots \ldots \ldots \ldots \ldots \ldots \ldots \ldots \ldots \ldots \ldots \ldots \ldots \ldots \ldots \ldots \ldots \ldots \ldots \ldots \ldots \ldots \ldots \ldots \ldots \ldots \ldots$ $i$ i

ACKNOWLEDGHENTS $\ldots \ldots \ldots \ldots \ldots \ldots \ldots \ldots \ldots \ldots \ldots \ldots \ldots \ldots \ldots \ldots \ldots \ldots \ldots \ldots \ldots \ldots \ldots \ldots \ldots$

1.0 INTRODUCTION $\ldots \ldots \ldots \ldots \ldots \ldots \ldots \ldots \ldots \ldots \ldots \ldots \ldots \ldots \ldots \ldots \ldots \ldots \ldots \ldots \ldots \ldots \ldots \ldots \ldots \ldots$ L

2.0 CONCLUSIONS $\ldots \ldots \ldots \ldots \ldots \ldots \ldots \ldots \ldots \ldots \ldots \ldots \ldots \ldots \ldots \ldots \ldots \ldots \ldots \ldots \ldots \ldots$

3.0 PROCESS DESCRIPTIOH $\ldots \ldots \ldots \ldots \ldots \ldots \ldots \ldots \ldots \ldots \ldots \ldots \ldots \ldots \ldots \ldots \ldots \ldots \ldots$

4.0 TEST DESCRLPTIONS $\ldots \ldots \ldots \ldots \ldots \ldots \ldots \ldots \ldots \ldots \ldots \ldots \ldots \ldots \ldots \ldots \ldots \ldots \ldots \ldots \ldots \ldots$

4.1 LARORATORY TESTS $\ldots \ldots \ldots \ldots \ldots \ldots \ldots \ldots \ldots \ldots \ldots \ldots \ldots \ldots \ldots \ldots \ldots \ldots \ldots \ldots \ldots, 7$

4.1.1 Composition and Physical Propertites ............... 7

4.1 .2 Melting properties ...........................

4.1.3 Estinate of Volune Roduction $\ldots \ldots \ldots \ldots \ldots \ldots \ldots \ldots \ldots \ldots \ldots, 12$

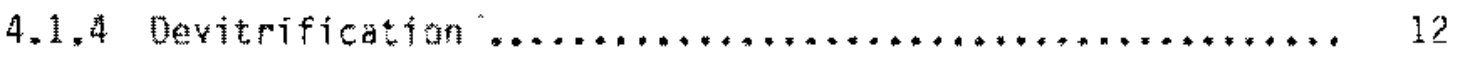

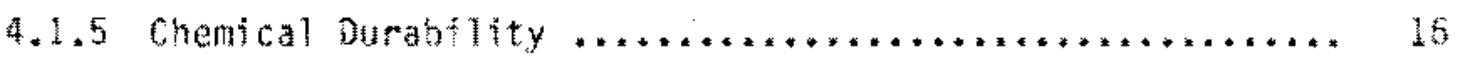

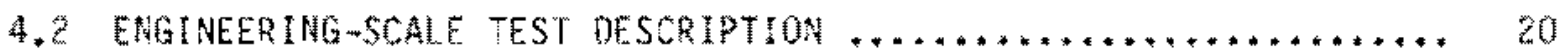

5.0 ENGINEERUNG-SCALE TEST RESLLTS ANE ANALYSIS $\ldots \ldots \ldots \ldots \ldots \ldots \ldots \ldots \ldots .27$

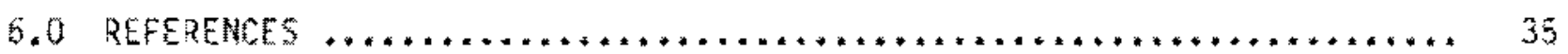


FIGURES

1 operatiny Sequence of in 5 th vitrification system .............. b

2 Viscosity Behavior of Gak Ridge National haboratory Subsoll as a

function of Temperature $\ldots \ldots \ldots \ldots \ldots \ldots \ldots \ldots \ldots \ldots \ldots \ldots \ldots \ldots \ldots \ldots \ldots \ldots$

3 Viscosity Behavior of $50 / 50$ soll/Limestone as a Function of

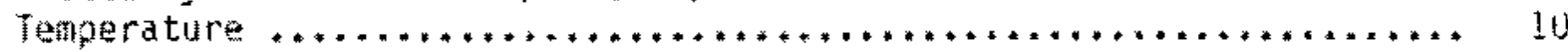

4 Electrical Conductivity of Gak Ridge National Laboratory in Situ

vitriffation 5011 and $50 / 50$ vol soil and Dolonite ............. lí

5 Estunated Cool-hown Rate at the Face of an In stitu Vitrification

Monolith and Heat Treatinent used on $50 / 50$ soll/0olonite .......... 13

6 X-kay olffractometry Results for Oak Ridge National Laboratory

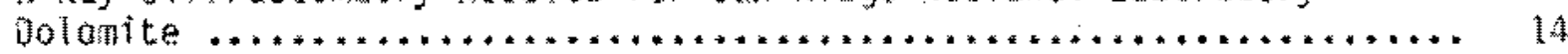

$7 \quad x-R a y$ Diffactometry aesults of Devicrified Oak Ridge National

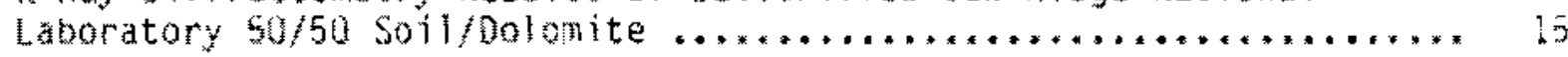

8 Heat-Trated 50/50 Oak Ridge National Laboratory Soll/0olonite

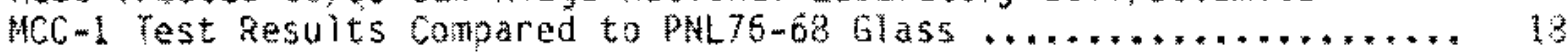

9 Heat-Treated 50/S0 Oak Ridge National Laboratory Soll/00lomithe Elemental Concentrations from MCC-3 Tests as a Function of

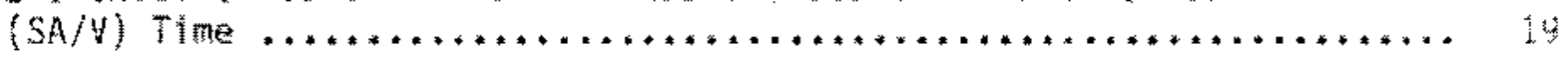

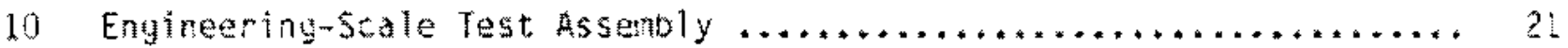

I1 A-phase and Buphase volts Versus Run Tine $\ldots \ldots \ldots \ldots \ldots \ldots \ldots \ldots \ldots \ldots \ldots$.

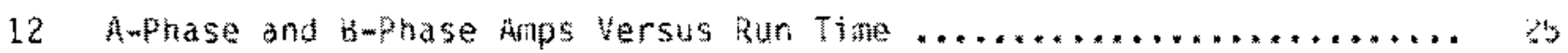

l' A-Phate and B.Phase kilowatts Versus Run Time ................. 25

14 Temperature of the $0.15-, 0.25-, 0.41-$, and 0.56 in Thermocouple

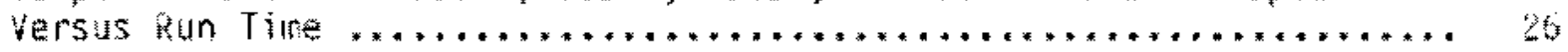

I5 Jff-Gas Sample Systen for Enyineering-Scale Uak Ridge Natonal

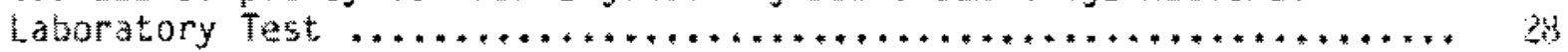

16 Projected Anount of Cesium and Strontium in the of tovas System

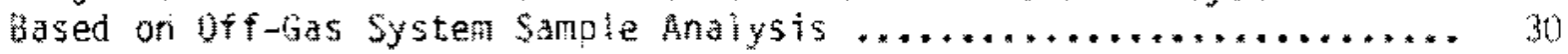

17 Heat-Treated $60 / 325011 / 00$ lonte MCC-1 Test Results Campared to

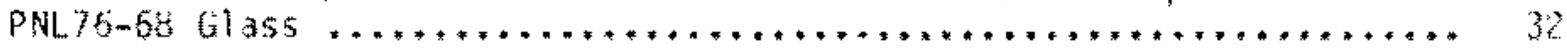


18 Comparison of Engineering-5cale sollhimestone to Laboratory soil/Limestone 


\section{TABLES}

1 Scales of Testing Units for Developing Technology .............. 1

2 Chemical Composition of Dak Ridge National Laboratory Matarlals as Determined by Inductively coupled.PTasma Analysis $\ldots \ldots \ldots \ldots \ldots \ldots \ldots .8$

3 Immersion Density of Oak Ridge Natfonal Laboratory In Situ

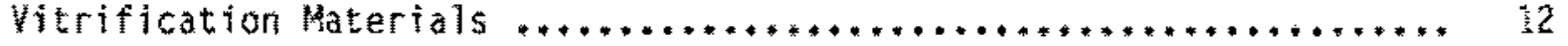

4 Predicted and Actual Data Obtained fron In Situ Vitrification Oak Ridge National Laboratory Engineering-Scale Tests .......... 2 .

5 Scrub Systen Sample Analysts .............................. 29

6 Nornalized Chemical Analys is of a Single core Sample from Engineering-Scale Test 


\subsection{INTROOUCTION}

Pacific Northwest Laboratory (PNL) has successfulty perforthed laboratory and engineeringmale tests of the in situ vitrification (ISt) process on actual Dak Ridge National Laboratory (ORNL) soil and linestone. In situ vitrim fication is an energing in-ground thermal treatinent technoiogy that fixes radiactive contamination in soll by converting it to glass and crystalline waste form.

PNL began developing ISV technology in 1980 under contract to the 0.5 . Gepartment of Energy (OOE) (Brouns, Buelt, and Bonner 1983). Since that the, numerous experimental tests using a variety of conditions and waste types have been conducted (0ma et a). 1983; Timeman and ona 1984; Timerman et a 1983). A Targe-scale ISV unit was designed, fabricated, and tested (auelt and Carter 1986). The large-scale unit was designed for processing transuraniccontaminated soil, but the design is adaptable to variety of waste types (Guelt and Frein 1986), including Dak kidge contaminated seepage pits and trenches.

Table 1 describes the dfferent scales of tasting units that PNL used in developing $15 \mathrm{~V}$ technology. The successful results of 47 bench-, engineering-, pllot-, and larger-scale tasts proved the feasloility of the process. Economic studies indicate that tremendous economies of scale are attainable with the 154 process (oma et al. 1983$)$.

TABLE 1. Scales of Testing Units for Developing Technology

\begin{tabular}{|c|c|c|c|}
\hline Equiphent size & $\begin{array}{l}\text { Electrode } \\
\text { Separation }\end{array}$ & Slock $5 i z e$ & $\begin{array}{c}\text { Tests } \\
\text { Completedal }\end{array}$ \\
\hline Bench-5cale & 4 in & $1 \tan 2075$ & 4 \\
\hline Engtneering-5cale & 9 to 15 in. & 100 ib to i ton & 25 \\
\hline Pilot-Scale & 3 to $4 \mathrm{ft}$ & 10 to 50 tons & 14 \\
\hline Large-scale & 11 to $19 \mathrm{ft}$ & 400 to 800 tons & 卒 \\
\hline
\end{tabular}

(a) As of July 1986. 
The objective of this study is to provide technical support for ISV techm nology application to ORNL intermediate-level waste. Evaluation areas of ORNL soll/1inestate were composition and physical properties, meltiny properties, volume reduction, crystal structure/devitrification, and chemical durability. Another mportant objective was determining ceslum and strontium retention in the vitrifled soll under conditions representative of actual ORNL $\$$ tes. The evaluation of the test results has indicated the feasibility of the process to vitrify the ORNL wastes. 


\subsection{CONCLUSIONS}

Process feasibility studies were successfully performed on two different processing scales to determine the technical support for ISV technology application to ORNL intermediate-level waste. In addition, analysis of the data from the two test scales provided the following conclusions regarding the performance of the ISV process as applied to ORNL soil and limestone found in the ORNL trenches and seepage pits.

- The evaluation of the ORNL soil, limestone, off-gas scrub system, off-gas high-efficiency particulate air (HEPA) filter and core samples from the vitrified mass confirm that ISV application is technically feasible.

- Soil to off-gas decontamination factors (DFs) as determined by the engineering-scale testing is $2.6 \times 10^{4}$ for cesium and $2.7 \times 10^{4}$ for strontium. These are equivalent to cesiun and strontium retention values in the molten soil of $99.996 \%$. Quantities of cesium and strontium tested in the engineering-scale were several orders of maynitude higher than those present in ORNL trenches and seepage pits.

- Volume reduction of greater than $40 \%$ may be expected. Volume reduction for the engineering-scale test was $60 \%$, eliminating concern for future subsidence.

- The soil-to-limestone ratio of the vitrified mass for the engineering scale test was $68 \mathrm{wt} \%$ soil to $32 \mathrm{wt} \%$ limestone. This improves durability significantly over that originally projected in the laboratory tests because of the reduced tendency to devitrify and the higher silica content.

- No migration of cesium was detected to the uncontaminated surrounding soil. The same behavior is expected for strontinum although not analytically determined.

- The dissolution rates at $90^{\circ} \mathrm{C}$ as determined by MCC-1 (1986) testing of the vitrified mass sample is equal to or less than those of 
PNL76-68 high-level waste glass. In addition, once the ISY vitrifled product has cooled, the anticipated storage temperature would be essentially ambient ground temperature, and dissolution rates could be as nuch as one or two orders of magnitude lower.

The laboratory and engineering-scale testing indicated the potential for ISV to treat the trenches and seepage pit at the ORNL contaminated waste sites. Based on the results of these feasibility tests, adequate technical bases are available to proceed with a pilot-scale denonstration on a simulated trench at 0RNL. 


\subsection{PROCESS DESCRIPTION}

The ISV process as applied to contaminated soil stabilization involves the insertion of electrodes into the soil, typically in a square array. A starter path for electric current is established by using a sinall amount of a graphite and glass frit mixture placed between the electrodes on the soil surface. Dissipation of power through the starter material creates temperatures high enough to melt a layer of soil, establishing a molten, conductive path. This molten zone continues to grow downward and encompasses the contaminated soil. Rocks (if present), which are less dense, create a floating layer near the molten surface. The rocks are eventually incorporated into the molten mass.

Figure 1 illustrates the process sequence. At the high temperatures (approximately $1600^{\circ} \mathrm{C}$ ) created, organic materials pyrolyze, diffuse to the surface, and combust. This movement of gas through the melt may produce some porosity near the surface of the melt. Any off gases from the process are collected, treated, and monitored to ensure their environmentally safe release. Remaining ash, along with other noncombustible materials, dissolves or becomes encapsulated in the molten soil. Natural convective currents within the molten soil help distribute the stabilized materials uniformly. The molten soil cools to a durable glass and crystalline waste form resembling natural obsidian or basalt.

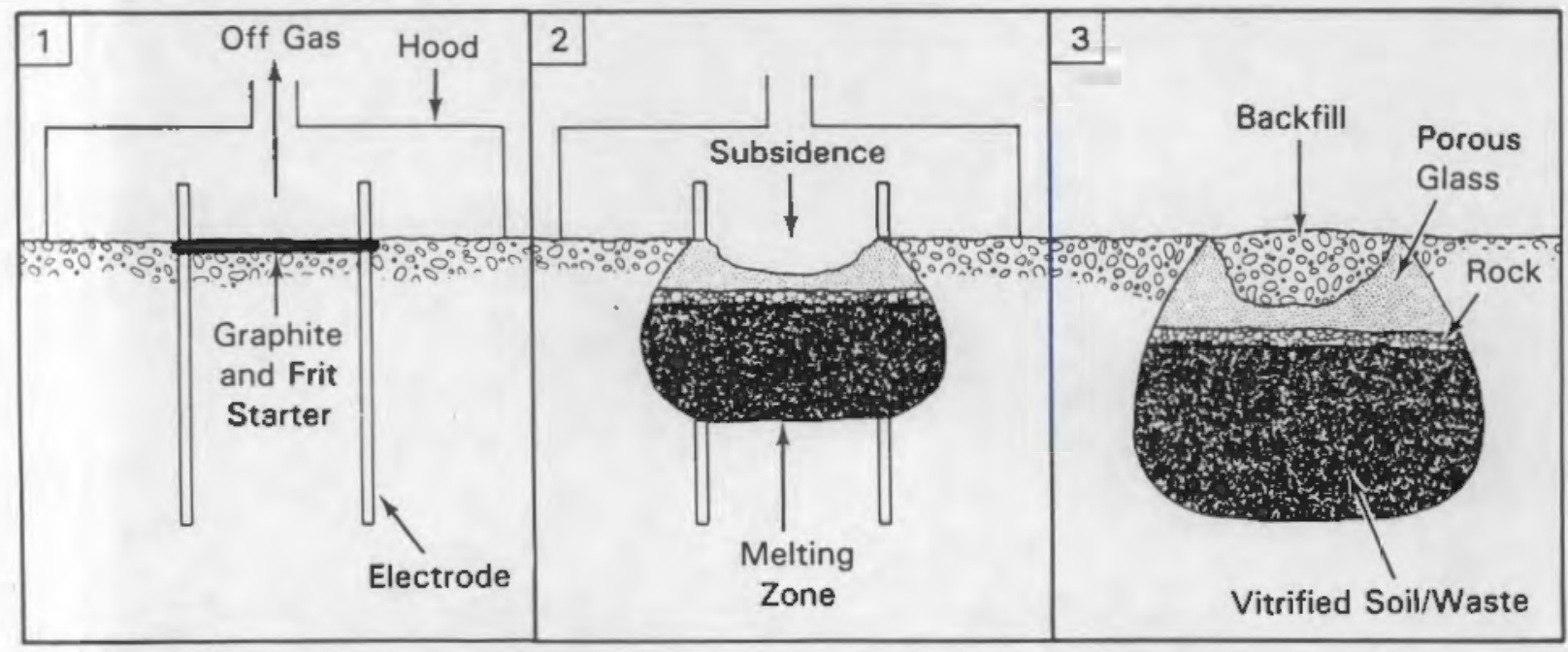

FIGURE 1. Operating Sequence of In Situ Vitrification Systeın 
The principles of the ISV operation are based on extensive joule-heated melter work perfomed at PNL for various nuclear waste immobilization projects (Buelt et al. 1979). The joule-heating principle operates by internal resistance heating of the conducting material as an electric current passes through the molten media. In ISV, the resistance decreases as the molten mass grows. To maintain a power level high enough (according to the formula $P=I^{2} R$ ) to continue melting more soil, the current must be increased. To accomplish the variable current during ISV processing, a power transformer with multiple voltage taps is used. At startup, the ISV process requires a high voltage potential and low amperage. As the melt progresses and resistance decreases, the lower voltage taps on the power transformer allow increased amperage to the melt, maintaining a high power level. The process will continue until heat losses from the melt approach the energy delivered to the molten soil via the electrodes or until power is discontinued to the melt.

A hood over the vitrification zone is maintained under a siight negative pressure to contain any hazardous gases or particulates that may be released. The hood also provides support for the electrodes. The negative pressure on the hood is supplied by the off-gas treatment system, which scrubs and filters any potentially hazardous components from the of $f$-gas stream. 


\subsection{TEST DESCRIPTIONS}

This section describes the laboratory and engineering-scale ISV testing of ORNL soil and limestone, the associated off-gas sampling equipment, and the specific test setup and operations used for both tests.

\subsection{LABORATORY TESTS}

To determine whether ISV could be used on ORNL soil, laboratory testing was conducted to evaluate the physical and melting characteristics of the ORNL soil, limestone, and a 50 vol\% soil/50 vol\% limestone mixture. Since the trenches are filled with limestone backfill, the 50/50 ratio was selected for product evaluation and characterization and to simulate a worst-case scenario. Because the primary duty of the ISV waste form is the containment of the waste components, a preliminary evaluation was made of the chemical durability of the predicted ISV product. The following characteristics and properties of ORNL. subsoil, limestone (dolomite), and 50/50 soil/limestone glass were investigated:

- composition and physical properties

- melting properties

- crystal structure/devitrification

- chemical durability

- estimate of volume reduction.

\subsubsection{Composition and Physical Properties}

Samples of ORNL soil and limestone were submitted for chemical analysis by inductively coupled plasma atomic emission spectroscopy (ICP). The ORNL soil and 1 imestone samples were heated to $1000^{\circ} \mathrm{C}$ for 16 hours to remove water and carbonates prior to analysis. The results are presented in Table 2 as normalized weight percent and mole percent. The soil was comprised primarily of silica and alumina. The relatively low concentrations of alkalis and alkaline earths explain the soil's high temperature selting point and viscosity and low electrical conductivity properties reported later. The ORNL "limestone" contained the equivalent of approximately 37 wt\% magnesium oxide. The ICP analysis, along with $x-$ ray diffraction (XRD) data that are presented later, 
TABLE 2. Chemical Composition of Oak Ridge National Laboratory Materials as Determined by Inductively-Coupled-Plasma Analysis (all materials fired at $>1000^{\circ} \mathrm{C}$ for 16 hours to remove water and carbonates)

\begin{tabular}{|c|c|c|c|c|c|c|}
\hline \multirow[b]{2}{*}{ Oxide } & \multicolumn{2}{|c|}{ ORNL SUL-SOII } & \multicolumn{2}{|c|}{ ORNL Dolomite } & \multicolumn{2}{|c|}{ Soil Dolomite } \\
\hline & wt $\%$ & mole \% & wt $\%$ & mole $\%$ & wt \% & mole $\%$ \\
\hline $\mathrm{Al}_{2} \mathrm{O}_{3}$ & 18.79 & 12.38 & 1.55 & 0.76 & 12.36 & 7.21 \\
\hline $\mathrm{B}_{2} \mathrm{O}_{3}$ & 0.08 & 0.08 & 0.08 & 0.06 & 0.06 & 0.05 \\
\hline $\mathrm{BaO}$ & 0.05 & 0.02 & 0.01 & 0.00 & 0.13 & 0.05 \\
\hline $\mathrm{CaO}$ & 1.57 & 1.88 & 49.67 & 44.07 & 20.09 & 21.29 \\
\hline $\mathrm{Fe}_{2} \mathrm{O}_{3}$ & 6.48 & 2.73 & 0.58 & 0.18 & 4.29 & 1.60 \\
\hline $\operatorname{Li}_{2} \mathrm{O}$ & 0.02 & 0.05 & 0.04 & 0.07 & 0.00 & 0.00 \\
\hline $\mathrm{MgO}$ & 3.01 & 5.03 & 37.00 & 45.73 & 15.76 & 23.24 \\
\hline $\mathrm{MnO}_{2}$ & 0.21 & 0.08 & 0.01 & 0.00 & 0.09 & 0.03 \\
\hline $\mathrm{Na}_{2} \mathrm{O}$ & 0.61 & 0.66 & 0.07 & 0.06 & 0.45 & 0.43 \\
\hline $\mathrm{SiO}_{2}$ & 68.23 & 76.31 & 10.87 & 9.01 & 46.17 & 45.67 \\
\hline SrO & 0.01 & 0.01 & 0.02 & 0.01 & 0.01 & 0.01 \\
\hline $\mathrm{TiO}_{2}$ & 0.88 & 0.74 & 0.04 & 0.03 & 0.56 & 0.41 \\
\hline $\mathrm{ZrO}_{2}$ & 0.06 & 0.03 & 0.06 & 0.02 & 0.03 & 0.01 \\
\hline Total & 100.00 & 100.00 & 100.00 & 100.00 & 100.00 & 100.00 \\
\hline
\end{tabular}

indicated that the ORNL limestone was magnesium-calcium-carbonate, i.e., dolomite. Examination of the concentrations of $\mathrm{SiO}_{2}$ and $\mathrm{CaO}$ revealed that weight percent concentrations of soil and 1 imestone in the $50 / 50$ mixture are $62 \%$ soil and $38 \%$ limestone. The weight percentages differ from the volume percentage because of different weight losses upon heating and different bulk densities of the two components.

\subsubsection{Melting Properties}

A sample of ORNL soil was placed in a Pt crucible and heated to $1650^{\circ} \mathrm{C}$ in air. The fusing temperature of the pure soil was observed to be between $1200^{\circ} \mathrm{C}$ and $1400^{\circ} \mathrm{C}$. Some tendency toward melt foaming was observed above $1400^{\circ} \mathrm{C}$. Soil heated to $1650^{\circ} \mathrm{C}$ and quenched to room temperature appeared vitreous with no observed devitrification. The viscosity behavior of this resulting ylass is represented in Figure 2. The temperature at which the viscosity is 100 poise 


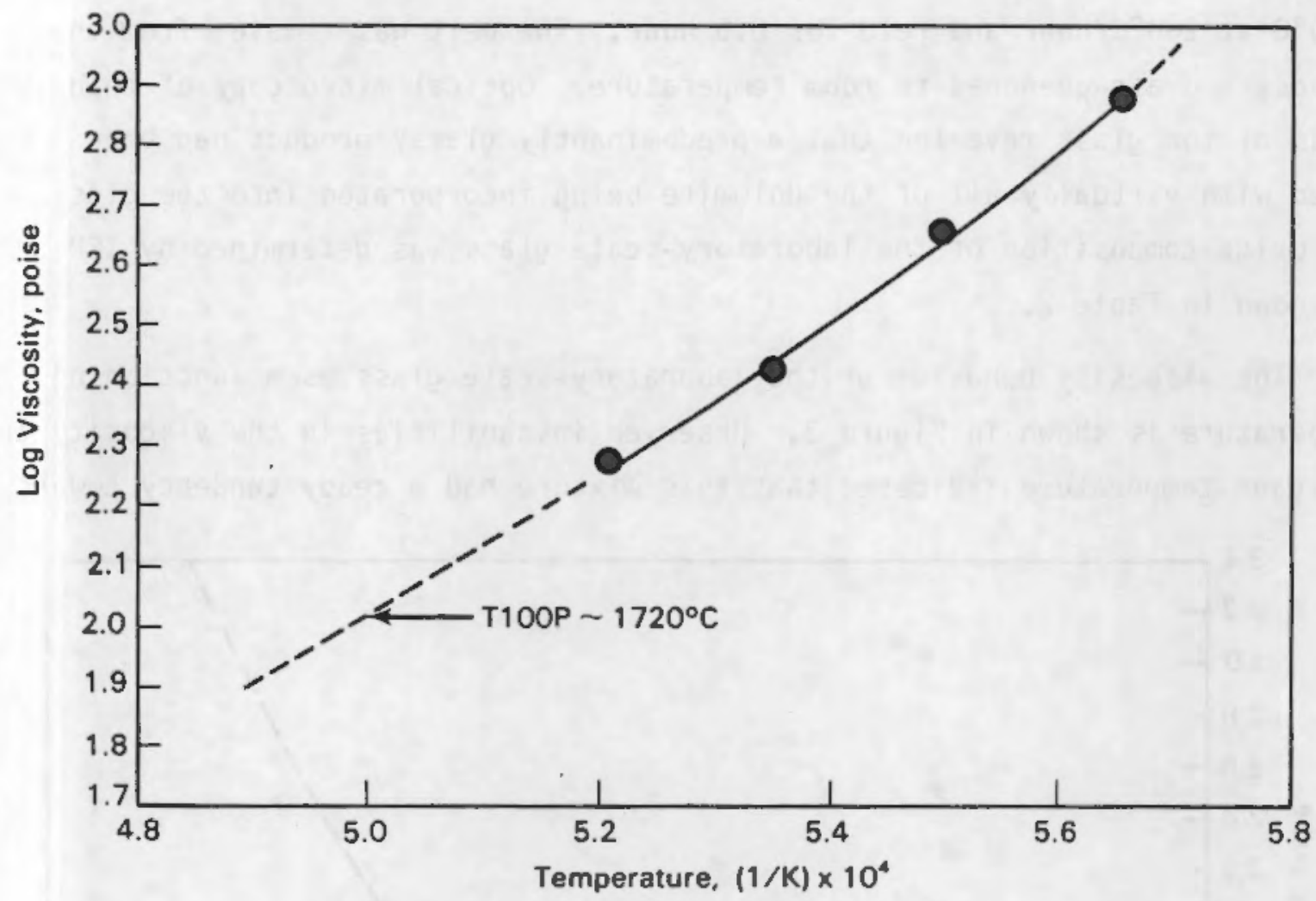

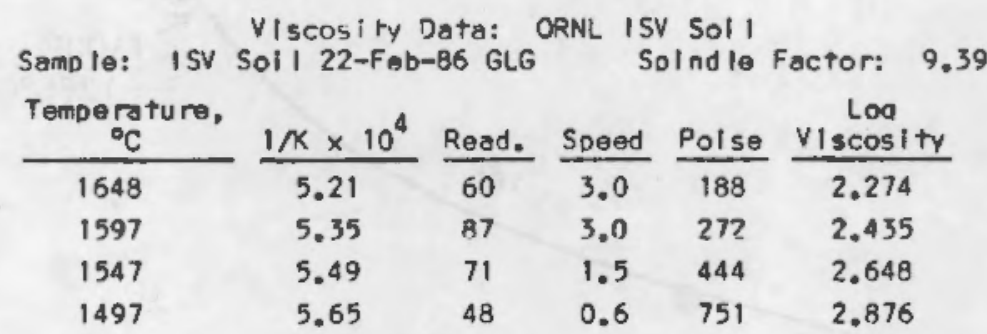

FIGURE 2. Viscosity Behavior of Oak Ridge National Laboratory Subsoil as a Function of Temperature

(TlUUP) is above $1650^{\circ} \mathrm{C}$ (the maximum temperature of the furnace used in this study) and is extrapolated to be $1720^{\circ} \mathrm{C}$. The smooth viscosity curve suggests the pure soil produces a glass with little tendency toward devitrification over the temperature range measured.

To estimate the meltiny composition and conditions of the URNL ISV site, a layered mixture of 50 vol\% soil and 50 vol\% $-20 /+100$ mesh dolomite (soil on top) was placed in a platinum/rnodium crucible and held at $1000^{\circ} \mathrm{C}$ for 16 nours to release off gas and avoid melt foaming. The sample was then heated to 
$1600^{\circ} \mathrm{C}$ at $200^{\circ} \mathrm{C} /$ hour and held for 0.5 hour. The melt was removed from the furnace and air-quenched to room temperature. Optical microscopy of thin sections of the glass revealed that a predominantly glassy product had been produced with virtually all of the dolomite being incorporated into the glass. The oxide composition of the laboratory-scale glass was deternined by ICP and is shown in Table 2.

The viscosity behavior of the laboratory-scale glass as a function of temperature is shown in Figure 3. Ubserved instabilities in the viscosity at constant temperature indicated that this mixture had a ready tendency toward

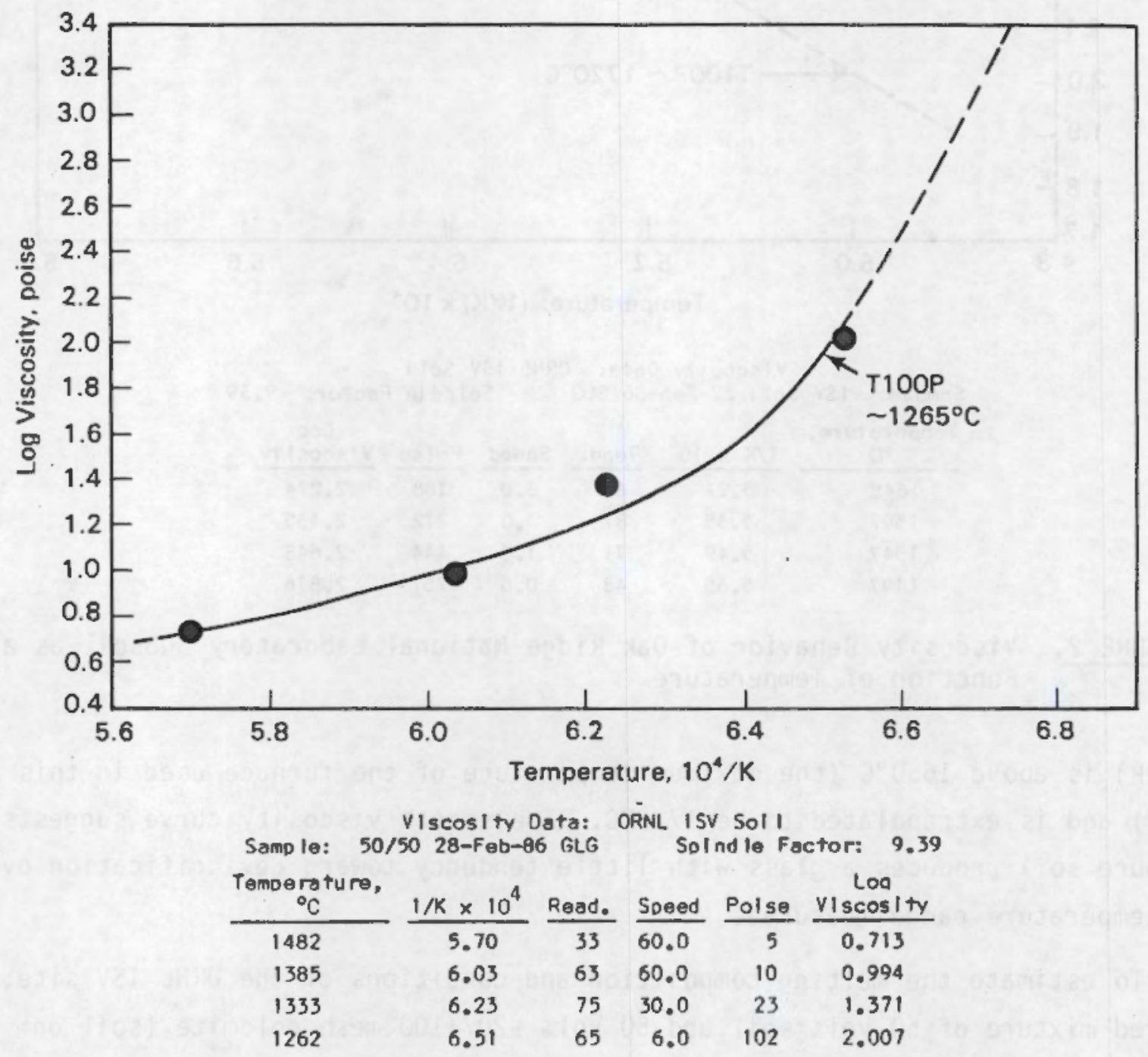

FIGURE 3. Viscosity Behavior of $50 / 50$ Soil/Linestone as a Function of Temperature 
devitrification. The T100P of the glass was determined to be $1265^{\circ} \mathrm{C}$, significantly lower than pure soil, indicating a lower ISV processiny temperature with the mixture. Crystalline material was observed in fibers pulled from the melt at temperatures as high as $1350^{\circ} \mathrm{C}$ while the bulk of the melt was quite fluid. Devitrification can be avoided, however, by increasing the silica content from higher soil concentrations, as achieved in the subsequent engineering-scale test.

The electrical conductivity behavior of melts of pure solid and the laboratory-scale melt were measured as a function of temperature using a twoprobe method (Chick et al. 1984). Figure 4 shows that the laboratory-scale glass was approximately 25 times more conductive than pure soil at $1500^{\circ} \mathrm{C}$. However, at the temperatures corresponding to 100 poise melt viscosity $\left(1265^{\circ} \mathrm{C}\right.$ for $50 / 50 \mathrm{soil} / \mathrm{dol}$ omite, $1720^{\circ} \mathrm{C}$ for soil), the electrical conductivities were nearly equal at about $0.035(\mathrm{ohm} \cdot \mathrm{cm})^{-1}$.

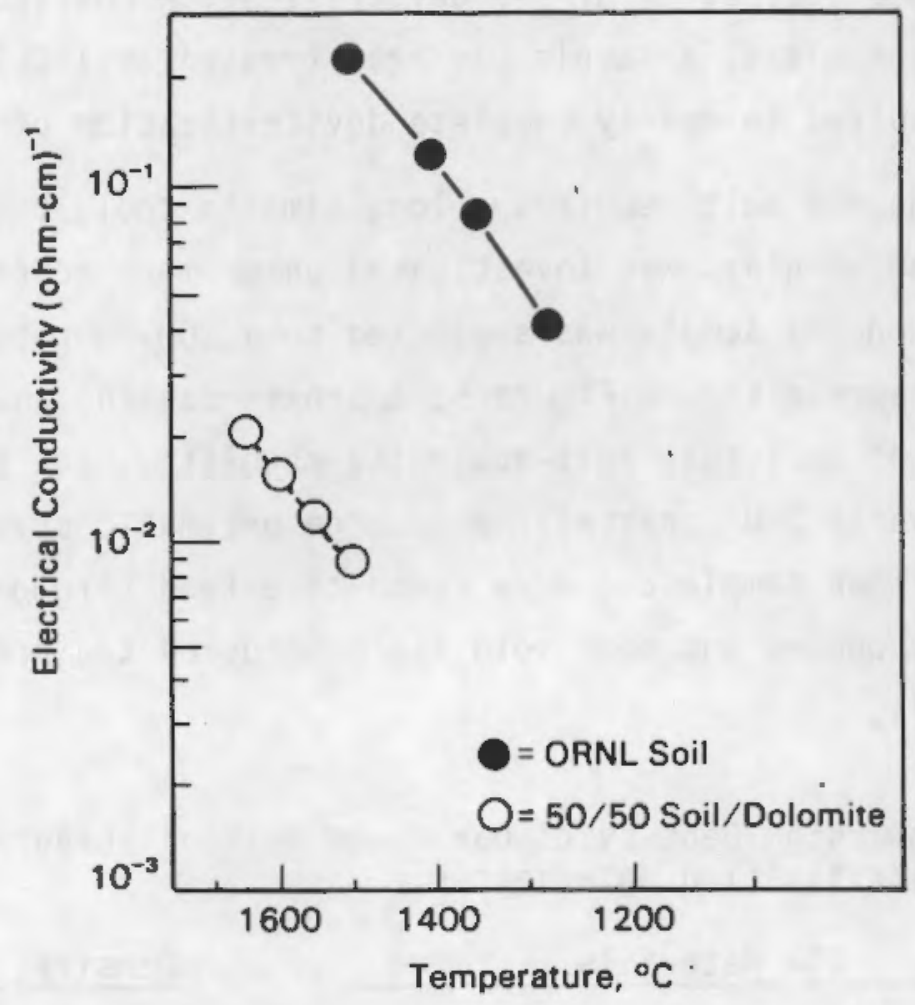

FIGURE 4. Electrical Conductivity of Oak Ridge National Laboratory In Situ Vitrification Soil and 50/50 Vol\% Soil and Dolomite 


\subsubsection{Estimate of Volume Reduction}

Immersion density determinations were performed on the dolomite, vitrified soil, air quenched (vitreous) 50/50 soil/dolomite, and heat-treated (devitrified) $50 / 50$ soil/dolomite. The results are listed in Table 3 . Since the pack densities of the dolomite and soil were approximately $1.6 \mathrm{~g} / \mathrm{cm}^{3}$ and the resulting density of $50 / 50$ soil/dolomite glass was approximately $2.9 \mathrm{~g} / \mathrm{cm}^{3}$, the ISV process could be expected to result in a volume reduction of approximately $45 \%$. Devitrification of the soil/dolomite glass resulted in a $3 \%$ volume reduction. The devitrification of glass can produce volume changes that of ten result in microcracking, shrinkage voids, and a general increase in surface area. Since elemental release from a waste form is a function of the exposed surface area, the chemical durability of the ISV product nay be adversely affected.

\subsubsection{Devitrification}

To obtain some indication of the devitrification characteristics of the $50 / 50$ soil/dolomite glass, a sample was heat treated at $1000^{\circ} \mathrm{C}$ for 8 hours in air. This resulted in nearly complete devitrification of the glass sample.

Since a large ISV melt requires a long time to cool, the devitrification behavior of the $50 / 50 \mathrm{glass}$ was investigated under more representative conditions. An air-quenched sample was subjected to a 200 -hour heat treatment. The heat treatment, represented in Figure 5, approximates the anticipated cool-down rate at the face of an actual full-scale ISV monolith. The heat-treated sample appeared to be nearly $100 \%$ crystalline. Large prismatic crystals were apparent on the surface of the sample and were found to extend throughout the bulk. other crystalline phases and some void space occupied the areas between the prismatic crystals.

TABLE 3. Immersion Density of Oak Ridge National Laboratory In Situ Vitrification Materials

ISV Materials

ISV Materials

Dolomite

Subsoil

$50 / 50$ Soil/Dolomite (vitrified) $50 / 50$ Soil/Dolomite (devitrified)

Density, $\mathrm{g} / \mathrm{cm}^{3}$

2.96 


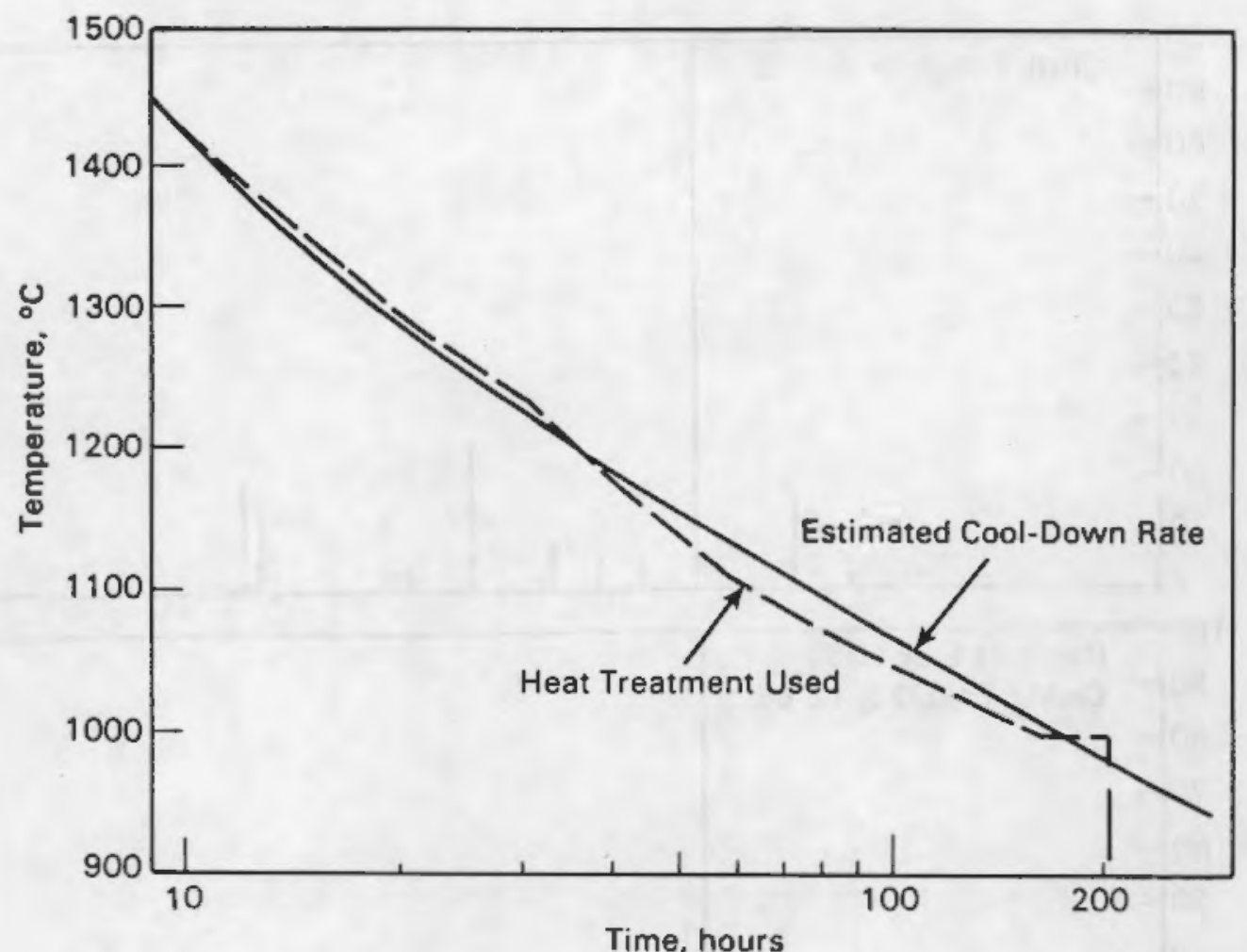

FIGURE 5. Estimated Cool-Down Rate at the Face of an In Situ Vitrification Monolith and Heat Treatment Used on 50/50 Soil/Dolomite

Samples of the dolomite and devitrified $50 / 50$ soil/dolonite were submitted for powder XRD analysis. Figures 6 and 7 represent the position and relative intensity of the resulting diffraction peaks. Standard XRD patterns are also represented for comparison. The locations of the main peaks in Figure 6 confirm that the ORNL limestone is actually dolomite $\left[\mathrm{CaMg}\left(\mathrm{CO}_{3}\right)_{2}\right]$ containing some quartz.

The XKD pattern for the devitrified $50 / 50$ soil/dolomite (Figure 7 ) is more complex. Several crystalline phases are present. Identification of the specific crystalline phases is difficult since there are a whole series of solid solutions permissible in the $\mathrm{Ca}, \mathrm{Mg}, \mathrm{Al}$, Fe silicate systen. The major crystalline phase appears to be very similar in structure to fassaite, which is a diopside mineral $\left(\mathrm{CaMgSi}_{2} \mathrm{O}_{6}\right.$ ) with some substitution of aluminum for magnesium and silicon. Iron, as well as aluminum, can substitute for some of the calcium, magnesium, and/or silicon in diopside. Some differences between the 

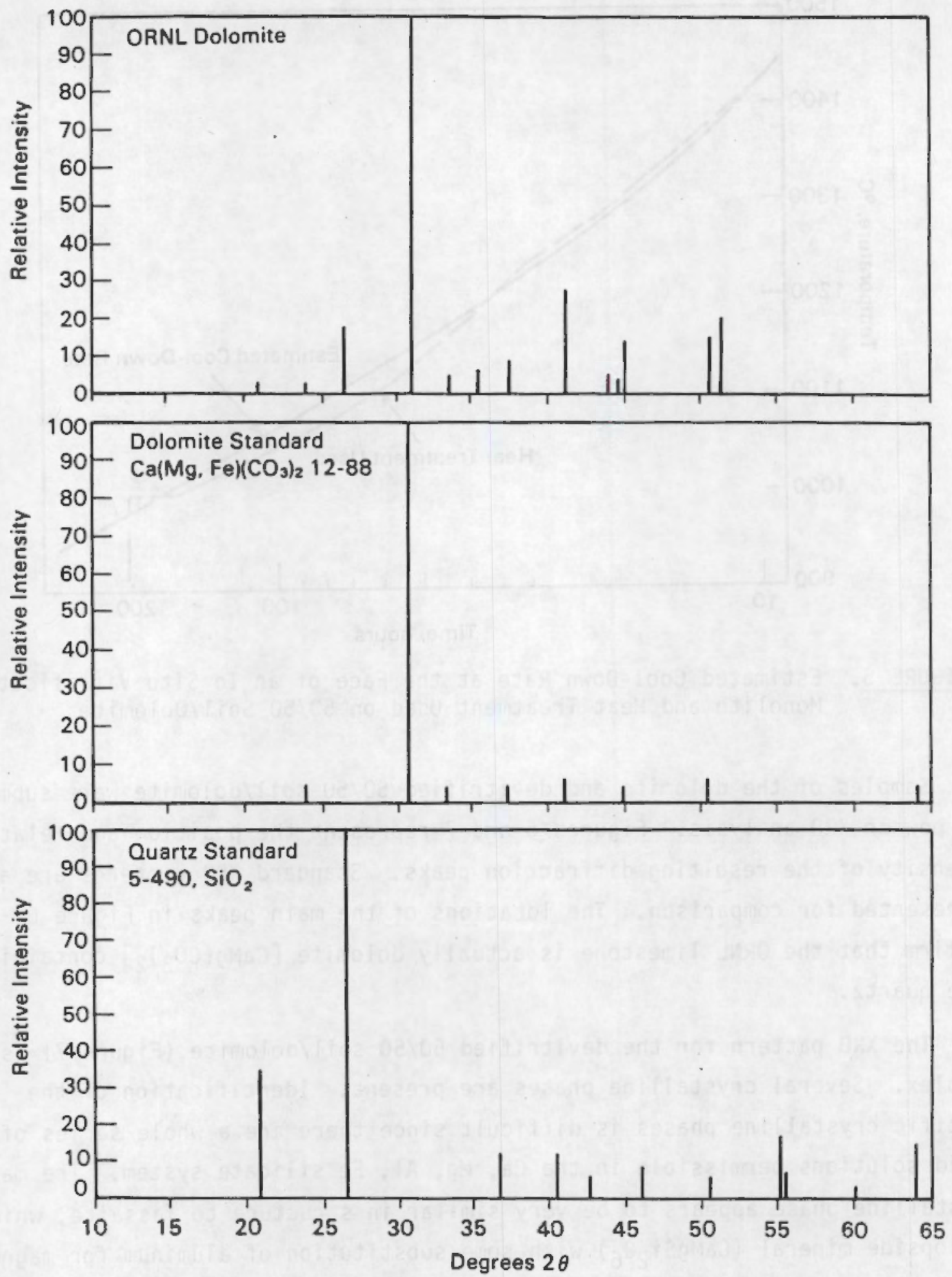

FIGURE 6. X-Ray Diffractometry Results for Oak Ridge National Laboratory Dolomite 

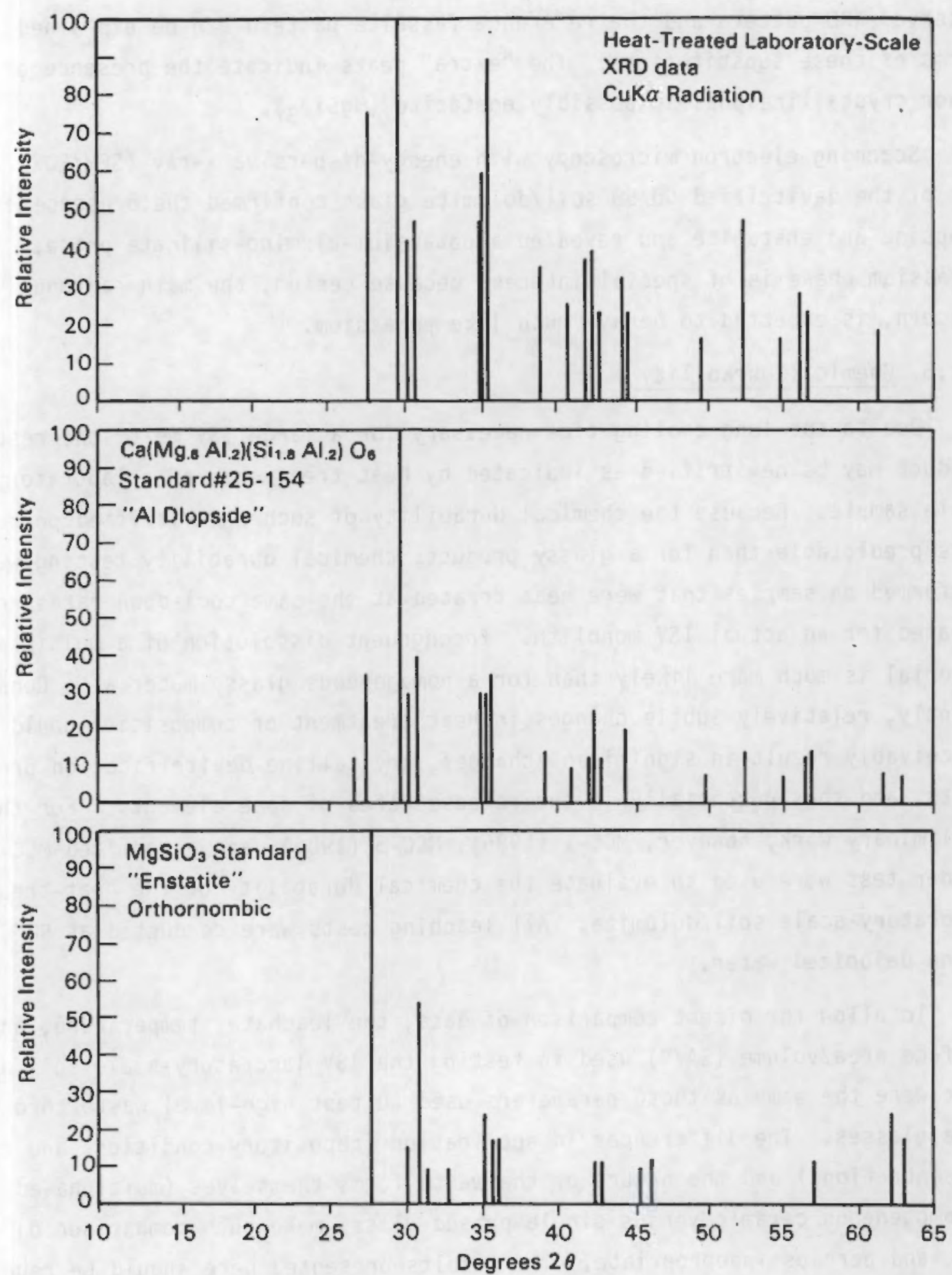

FIGURE 7. X-Ray Diffractometry Results of Devitrified Oak Ridge National Laboratory 50/50 Soil Dolomite 
observed XRD pattern and the reference fassaite pattern can be explained in terms of these substitutions. The "extra" peaks indicate the presence of other minor crystalline phases, possibly enstatite $\left(\mathrm{MgSiO}_{3}\right)$.

Scanning electron microscopy with energy-dispersive $x$-ray (SEM/EDX) analysis of the devitrified 50/50 soil/dolomite glass confirmed the presence of diopside and enstatite and revealed a potassium-alumino-silicate phase. The potassium phase is of special interest because cesium, the main radionuclide of concern, is expected to behave much like potassium.

\subsubsection{Chemical Durability}

Due to the long cooling time necessary for a large ISV melt, the resulting product may be devitrified as indicated by heat treatments of a laboratoryscale sample. Because the chemical durability of such a devitrified product is less predictable than for a glassy product, chemical durability testing was performed on samples that were heat treated at the same cool-down rates anticipated for an actual ISV monolith. Incongruent dissolution of a multiphased material is much more likely than for a homogeneous glassy material. Consequently, relatively subtle changes in heat treatment or composition could conceivably result in significant changes, crystalline devitrification products, and thus potentially in the release rates of some elements. For this preliminary work, however, MCC-1 (1986), MCC-3 (1986), and a modified MCC-3 powder test were used to evaluate the chemical durability of the heat-treated laboratory-scale soil/dolomite. All leaching tests were conducted at $90^{\circ} \mathrm{C}$ using deionized water.

To allow for direct comparison of data, the leachate, temperature, and surface area/volume (SA/V) used in testing the ISV laboratory-scale soil product were the same as those parameters used to test high-level waste borosilicate glasses. The differences in appiication (repository conditions and curie concentrations) and the nature of the waste forms themselves (multiphased, inhomogeneous ceramic versus single-phased glass) make such comparison difficult and perhaps inappropriate. The results presented here should be regarded as preliminary. Further testing for long-term storage conditions are required to fully assess the ISV product as a suitable waste form. 
The results are given in terms of normalized elemental mass release which is calculated with use of the following equation:

$$
N R_{i}=m_{j} /\left(F_{i} \times S A\right)
$$

where $N R_{i}=$ normalized mass release of element $i\left(\mathrm{~g} / \mathrm{m}^{2}\right)$

$m_{i}=$ mass of element $i$ in leachate $(g)$

$F_{i}=$ fraction of element $i$ in glass (dimensionless)

$S A=$ surface area of monolith $\left(\mathrm{m}^{2}\right)$.

Elemental release values for the devitrified laboratory-scale soil product vary significantly, suggesting incongruent dissolution is occurring. In an inhomogeneous system such as the devitrified laboratory-scale ISV soil product, incongruent dissolution is expected. As reported earlier, XRD and SEM/EDX analyses identified the presence of diopside ( $\mathrm{Ca}, \mathrm{Mg}, \mathrm{Al}$, silicate), enstatite (Mg silicate), and a potassium-alumino-silicate phase in heat-treated laboratory-scale ISV product. The strontium- and cesium-bearing phases were not identified. The different dissolution rates of the individual mineral phases (and exposed surface areas of each of those phases) are reflected in the varying normalized elemental release values in Figure 8 . Normalized strontium release from the laboratory-scale ISV soil is 10 to 100 times that of PNL76-68 glass. Potassium release from the laboratory-scale soil/dolomite ISV product is at least a factor of two higher than the cesium release observed for PNL76-68 glass. These release rates need to be evaluated with regulatory criteria to determine whether silica or soil additives are necessary for anticipated 50/50 soil/1imestone mixtures.

Solubility of certain elements, particularly Si, has a significant effect on apparent dissolution rates. As the concentration of Si increases, the dissolution rate slows as the leachant becomes saturated with respect to Si. One way to observe the solubility effects in a waste form/dissolution system is to monitor changes in elemental concentrations (in the leachate) as a function of time. However, some solubility effects do not become apparent until after very 


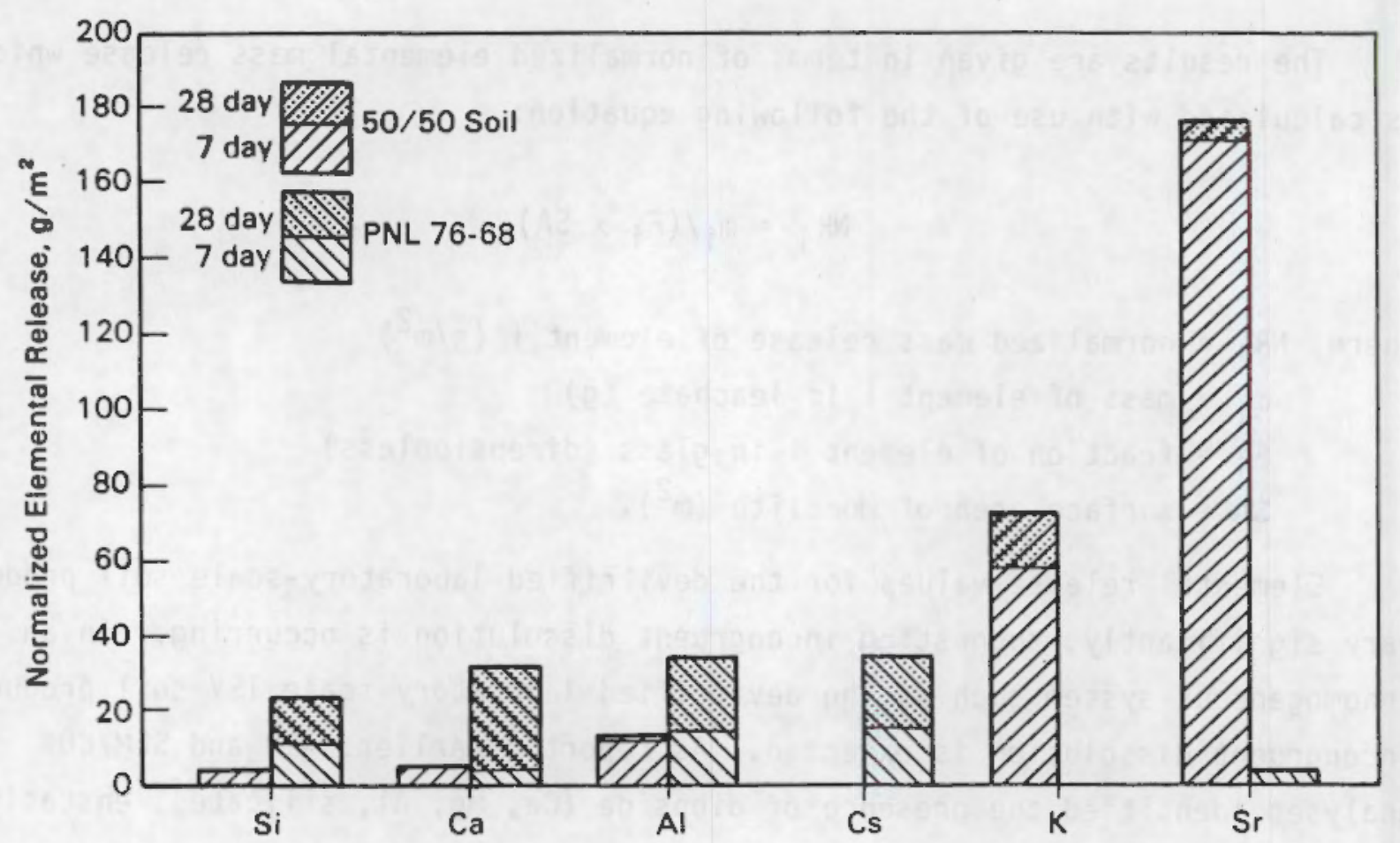

FIGURE 8. Heat-Treated 50/50 0ak Ridge National Laboratory Soil/Dolomite MCC-1 (Monolith) Test Results as Compared to PNL-76-68 Glass

long times. The concept that dissolution progress is a function of the $S A / V$ ratio of the sample multiplied by test duration, (SA/V)-time, can be used to observe these solubility effects in a reasonable amount of time.

Figure 9 is a $\log / \log$ plot of normalized elemental concentration as a function of (SA.time)/ $V$ for the laboratory-scale soil ISV product tested under modified MCC-3 conditions. (a) Note that on a $\log / \mathrm{log}$ plot, lines having unit slope represent constant rate of chanye, and lines having zero slope represent no apparent change. The " $\gamma$ " intercept (at $\log [(S A \cdot t i m e) / V]=0$ ) of a line having unit slope and going through any point on a functional curve will represent the average functional rate at that point. Incongruent dissolution is again apparent. The normalized elemental values do not lie near a single line; but the normalized release of $\mathrm{Si}, \mathrm{Al}$, and $\mathrm{K}$ parallel each other up to the point where $\mathrm{Si}$ and $\mathrm{Al}$ reach saturation and their elemental concentration levels out.

(a) Modifications included testing at various SA/V ratios with successive sampling and replenishing of the test solution. 


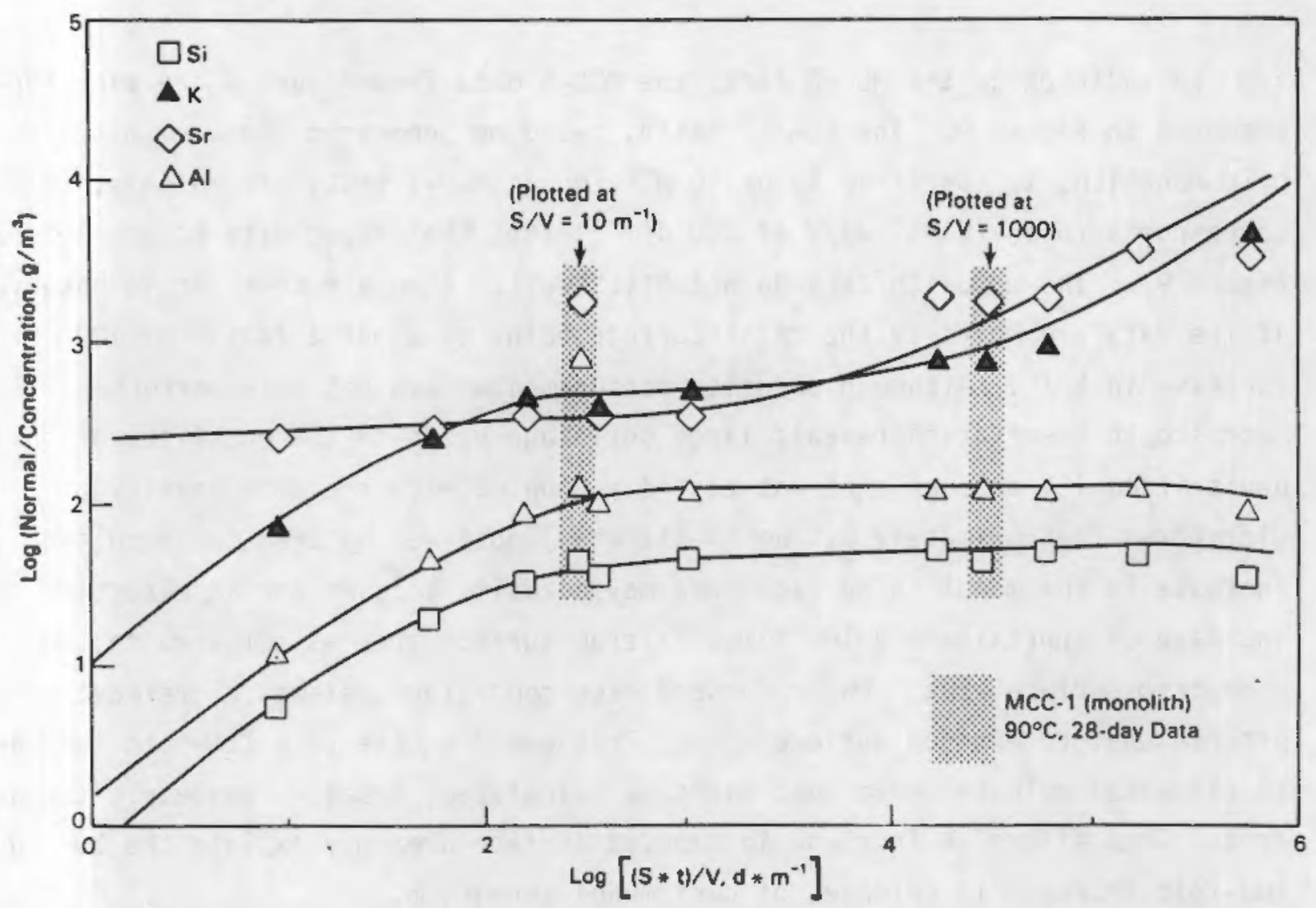

FIGURE 9. Heat-Treated 50/50 0ak Ridge National Laboratory Soil/Dolomite Elemental Concentrations from MCC-3 (Powder) Tests as a Function of $(S A / V) \cdot T$ ime

Potassium concentrations continue to rise at very high (SA-time)/V values, indicating that dissolution has not stopped but has slowed greatly.

Since the ISV product will be near the surface (not in a deep geological repository), flow rates will probably be relatively high. In this, case, the initial (forward) release rate will be most important. The forward rate for potassium from the soil ISV product is seen to be about 10 normalized $\mathrm{g} / \mathrm{m}^{2}$. The forward rate for strantium is between 10 and $100 \mathrm{~g} / \mathrm{m}^{2}$. The concentration of strontium in the leachate (due to the low level in the waste form) is near the detection limit for strontium using ICP, resulting in increased uncertainty in the data. As a point of reference, the 76-68 glass forward matrix dissolution rate is about $1 \mathrm{~g} / \mathrm{m}^{2}$. Again, comparison to regulatory criteria is necessary to determine whether an ISV waste form without durability additives is appropriate for this application. 
In addition to the $M C C-3$ data, the $M C C-1$ data from Figure 8 are also represented in Figure 9. The $(S A / V)$ ratio, based on geometric measurements of the bulk monolith, is specified to be $10 \mathrm{~m}^{-1}$ for an MCC-1 test. At 28 days, this corresponds to an (SA.time)/V of $280 \mathrm{~d}\left(\mathrm{~m}^{-1}\right.$ ) (see the shaded data to the left on Figure 9). The monolith data do not "fit" well. A much better fit is observed if the data are moved to the right corresponding to about a factor of 100 increase in SA/V. Although porosity measurements have not been performed, macroscopic observation reveals large shrinkage voids in the monoliths of the devitrified ISV product that was tested. Coupled with the high density of micropores (approximately $0.5 \mu \mathrm{m}$ in diameter) observed by SEM, the resulting increase in the monolith surface area may actually account for an effective increase of approximately 100 times in true surface area as compared to the geometric surface area. Under forward rate conditions, elemental release is proportional to exposed surface area. This would equate to a 100-fold increase in elemental release above what might be calculated, based on yeometric surface area. This effective increase in exposed surface area may explain the 10- to 100-fold increase in releases of cesium and strontium.

It is important to note that these tests were conducted at $90^{\circ} \mathrm{C}$. Once the ISV product has cooled, the anticipated storage temperature would be essentially ambient yround temperature. Dissolution rates could be as much as two orders of magnitude lower making the ISV waste form equivalent to the PNL76-68 high-level waste form. The leach data presented here apply oniy to 50/50 soil/ limestone waste forms. Higher soil concentrations improve leach resistance of cesium and strontium. Based on this analysis and the lack of firm regulatory criteria on which to evaluate the ISV waste form, no apparent reason was identified for the use of durability additives for the engineering-scale test.

\subsection{ENGINEERING-SCALE TEST DESCRIPTION}

The engineering-scale ISV test was performed on a 1/12-scale simulation of the ORNL Trench No. 7 without durability additives. The trench simulation contained actual ORNL soil and limestone supplied to PNL by ORNL. The limestone was crushed to $-1 / 4 \mathrm{in.}$, scaled to actual trench material. The vitrification test took place within a $2.4-\mathrm{m}$ high by $1.8-\mathrm{m}$ ( $8 \mathrm{ft}$ by $6 \mathrm{ft}$ ) diameter aluminum 
corrugated container. The engineering-scale power supply system consisted of a $30-k W$ Scott-Tee-connected transformer. The transformer has 16 voltage taps and is wired for secondary control with saturable reactors (Oma et al. 1983).

The engineering-scale test trench was constructed as shown in Figure 10. To avoid influence with the Hanford soil filler material, the ORNL soil was placed inside a metal ring $0.91-m$ in diameter and $0.74-m$ deep ( $36 \mathrm{in}$. by 29 in.). Thermocouples were placed at various increments to a depth of $0.56 \mathrm{~m}$. Hanford soil was placed below and around the metal retaining ring. ORNL soil was placed inside of the inetal ring to a depth of $0.45 \mathrm{~m}(17-3 / 4 \mathrm{in}$.). At the $0.45-m$ depth, a blended mixture of $1220 \mathrm{~g} \mathrm{Cs}_{2} \mathrm{CO}_{3}$ and $2780 \mathrm{~g} \mathrm{Sr}(\mathrm{OH})_{2}$ was placed in a $0.30-m$ (12 in.) square by $0.04-m(1-3 / 4$ in.) deep. These amounts, which were much higher in mass concentration than would be expected at the actual

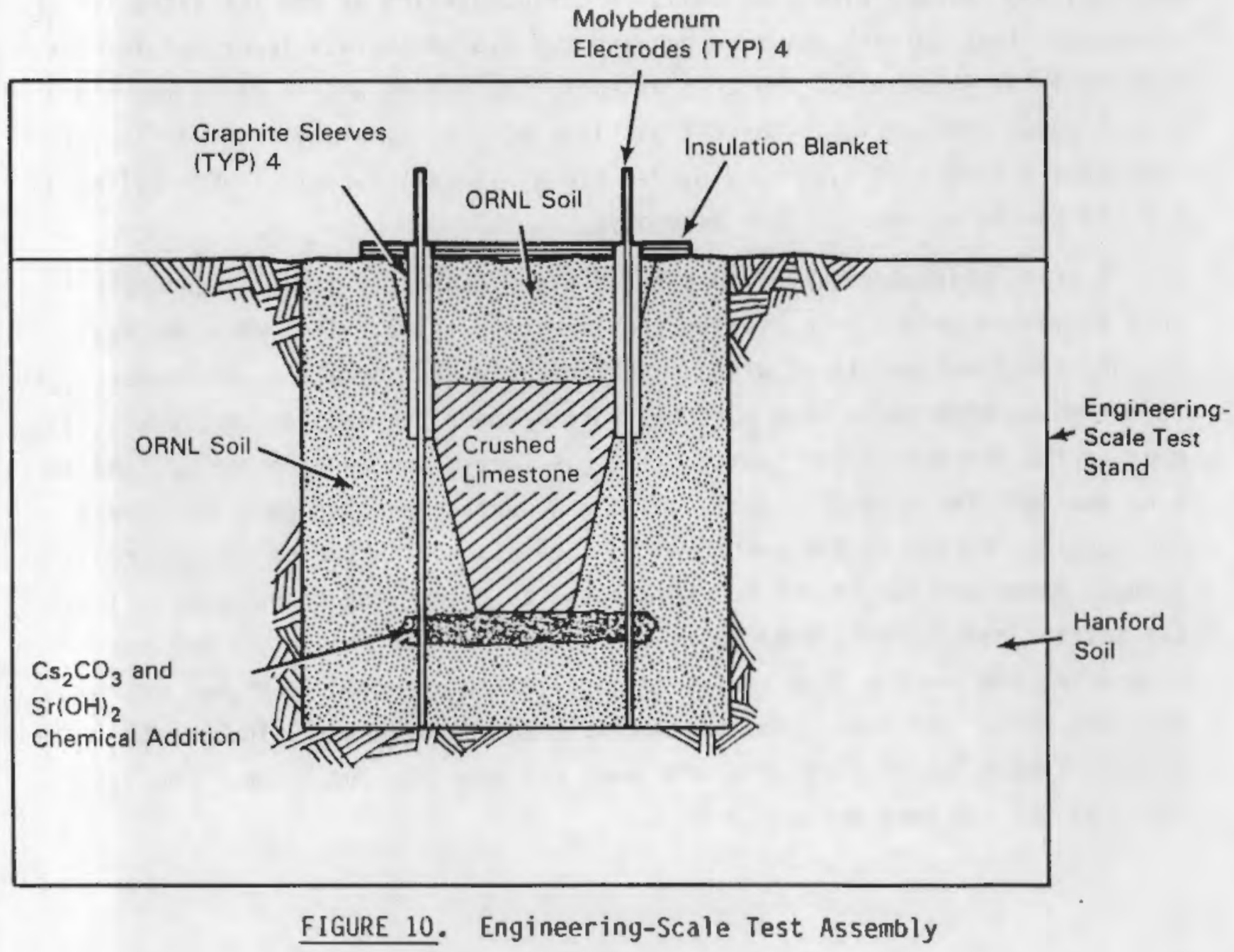


ORNL Trench No. 7, were based on detectability of cesium and strontium in the scrub solution and waste form. Wooden forms were then assembled to form a trench $0.43 \mathrm{~m}$ (17 in.) long (Figure 10). The area outside the forms was filled with ORNL soil. The crushed limestone was placed inside the form to a depth of $0.25 \mathrm{~m}(10 \mathrm{in.})$. The surface above the limestone was covered with ORNL soil. The wooden forms and the metal retaining ring were then removed.

Four electrodes were placed at a $0.23 \mathrm{~m}$ ( 9 in.) spacing in a square pattern. The electrodes were $1.9 \mathrm{~cm}$ diameter by $0.91-\mathrm{m} 1 \mathrm{ong}(3 / 4 \mathrm{in}$. by 36 in.) molybdenum with $5.1-\mathrm{crn}$ diameter by $0.36-\mathrm{m}$ long ( $2 \mathrm{in}$. by $14 \mathrm{in.}$ ) graphite sleeves placed over the molybdenuin electrodes. The annulus between the graphite and the molybdenum was filled with molybdenum powder for electrical continuity. A graphite and frit starter material was placed between the electrodes at a depth of $0.10 \mathrm{~m}$ ( $4 \mathrm{in.}$ ). The surface above the starter material was covered with ORNL soil. After completion of the simulated trench, the entire test surface was covered with two $2.5-\mathrm{cm}(1-\mathrm{in}$.$) layers of insula-$ tion material (kaowool). The test assembly was sealed and prepared for electrical power application. The off-gas line used to sample gaseous effluents contained a $0.30-\mathrm{m}$ by $0.30-\mathrm{m}$ by $0.29-\mathrm{m}$ ( 12 by 12 by $115 / 8 \mathrm{in}$.$) HEPA filter and$ a 3 LPM sample scrubber/filter assembly.

Initial startup resulted in a false start caused by insufficient molten soil formation before encountering the limestone layer. The melt zone had reached the limestone layer without sufficient glass formation, and several gas formation bubbles and a vent port had formed under the insulation blanket, disrupting the electrical continuity. The yas formations were broken up, the melt zone was refilled with ORNL soil, and a new surface starter path was forined. The test was restarted and continued to completion with two normal interruptions. Power was turned off for 10 minutes to change the transformer-voltage tap-setting range from 400 to 200 volts control and to change wiring in a saturable core reactor from series to parallel to accommodate higher current near the end of the test. The thernocouple at the $0.56-\mathrm{m}$ (22-in.) depth indicated a fusion temperature of $1000^{\circ} \mathrm{C}$ when the test was completed. The actual run time for the test was 8 hours. 
Table 4 shows predicted and actual data obtained from ISV/ORNL engineering-scale tests. Predicted data is based on a mathematical model developed for ISV (Oma et a1. 1983). In reviewing the data, note the close comparison of the actual test results to the model predictions. This close comparison provides a reasonable degree of confidence for prediction of the pilot-scale test. Note the difference under the "Actual" column between the mass of material treated versus the ISV mass produced. The difference in mass is due to the loss of volatile components (i.e., moisture, carbonates, etc.) during processing. Laboratory tests showed $23 \%$ motsture weight loss of the ORNL soil heated to $1000^{\circ} \mathrm{C}$ for 16 hours. Weight loss of the ORNL limestone heated to $1000^{\circ} \mathrm{C}$ for 16 hours was $42 \%$.

A description of the vitrified block after removal from the test assembly is given below:

- Subsidence from the surface was $0.30 \mathrm{~m}$ (12 in.), giving a volume reduction of $60 \%$.

- The surface of the melt zone was very sinooth with no porous cold cap observed. This feature maximizes volume reduction and eliminates concern for future subsidence.

TABLE 4. Predicted and Actual Data Obtained from In Situ Vitrification/0ak Ridge National Laboratory Engineering-Scale Tests

\begin{tabular}{llll} 
Run Time, $\mathrm{h}$ & Predicted & \multicolumn{1}{c}{ Actual } \\
\cline { 2 - 2 } Melt Oepth, m & 9.1 & 8.0 \\
Melt Width, m & 0.54 & 0.51 \\
Mass of Material Treated, kg & 0.53 & 0.51 to 0.60 \\
ISV Mass, kg & 160 & 173 \\
Heat Loss, kW & -- & 86 \\
Average Power, kW & 9.0 & -- \\
Energy, kWh & 17 & 17 \\
E/Mass, kWh/kg & 155 & 139
\end{tabular}


- The walls of the subsided area were vertical with a thickness of $1.3 \mathrm{~cm}(1 / 2 \mathrm{in.})$ on the north and south surfaces. The east and west faces, which contained the ends of the limestone trench, had no structural strength and crumbled during excavation. This indicates that during larger-scale applications sloughing may occur down the trench and the off-gas hood will have to be designed to accommodate such sloughing.

- The soil around the entire vitrified block, approximately 6.4 cin by $7.6 \mathrm{~cm}$ thick (2-1/2 in. by $3 \mathrm{in.})$, had changed to a red rusty color. This indicated a ferrous-to-ferric ratio change due to temperature but has no implications on processing behaviors.

The electrical data obtained from the engineering-scale test are shown in Figure 11, which gives A-phase and B-phase volts versus run time, and Figure 12, which gives $A$-phase and $B$-phase amps versus run time. Figure 13 shows $A$-phase and $B$-phase kilowatts versus run time. Figure 14 shows the temperature of the $0.15-, 0.25-, 0.41-$, and $0.56-m(6,10,16$, and $22 \mathrm{in.})$ thermocouple versus run

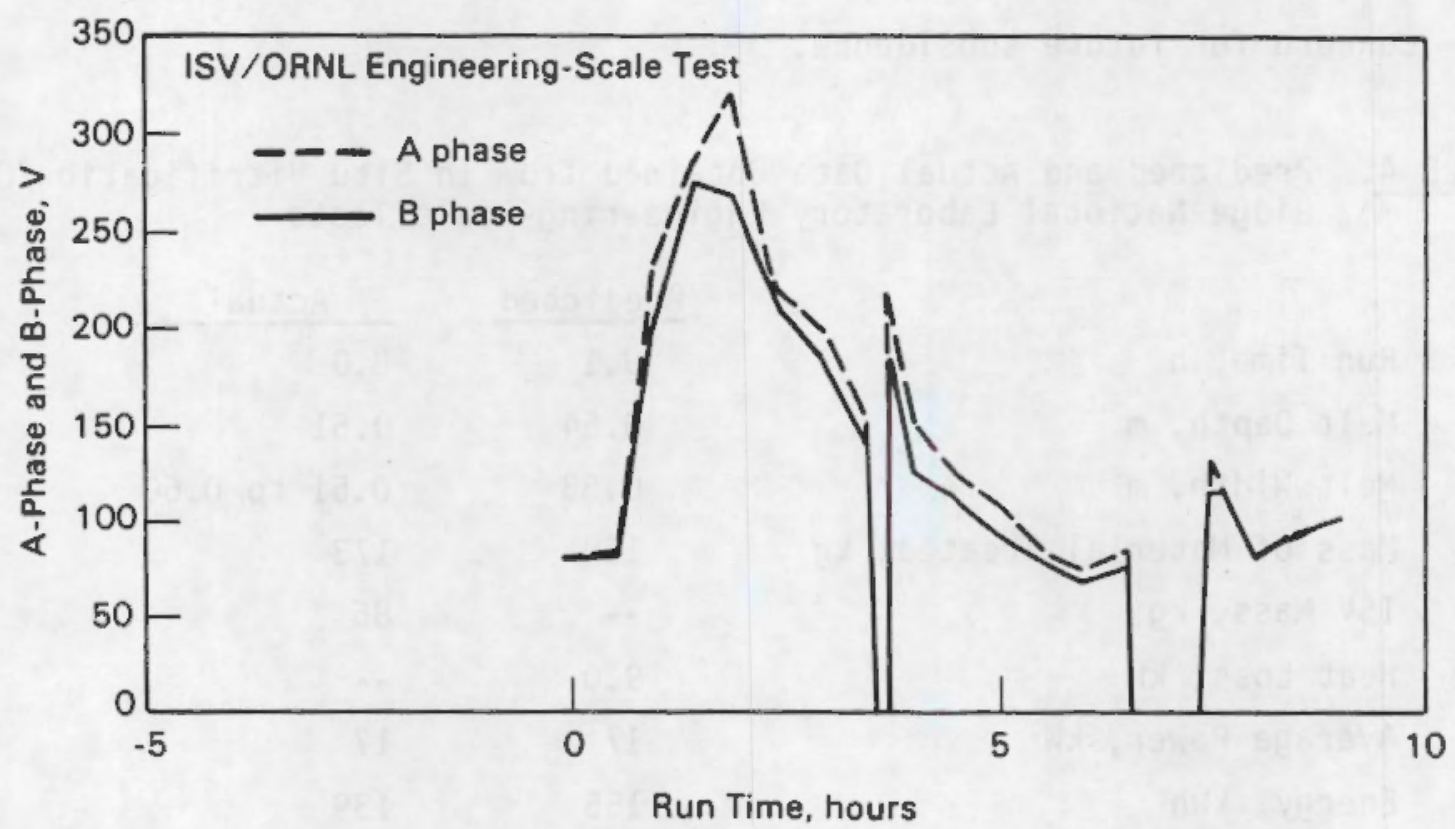

FIGURE 11. A-Phase and B-Phase Volts Versus Run Time 


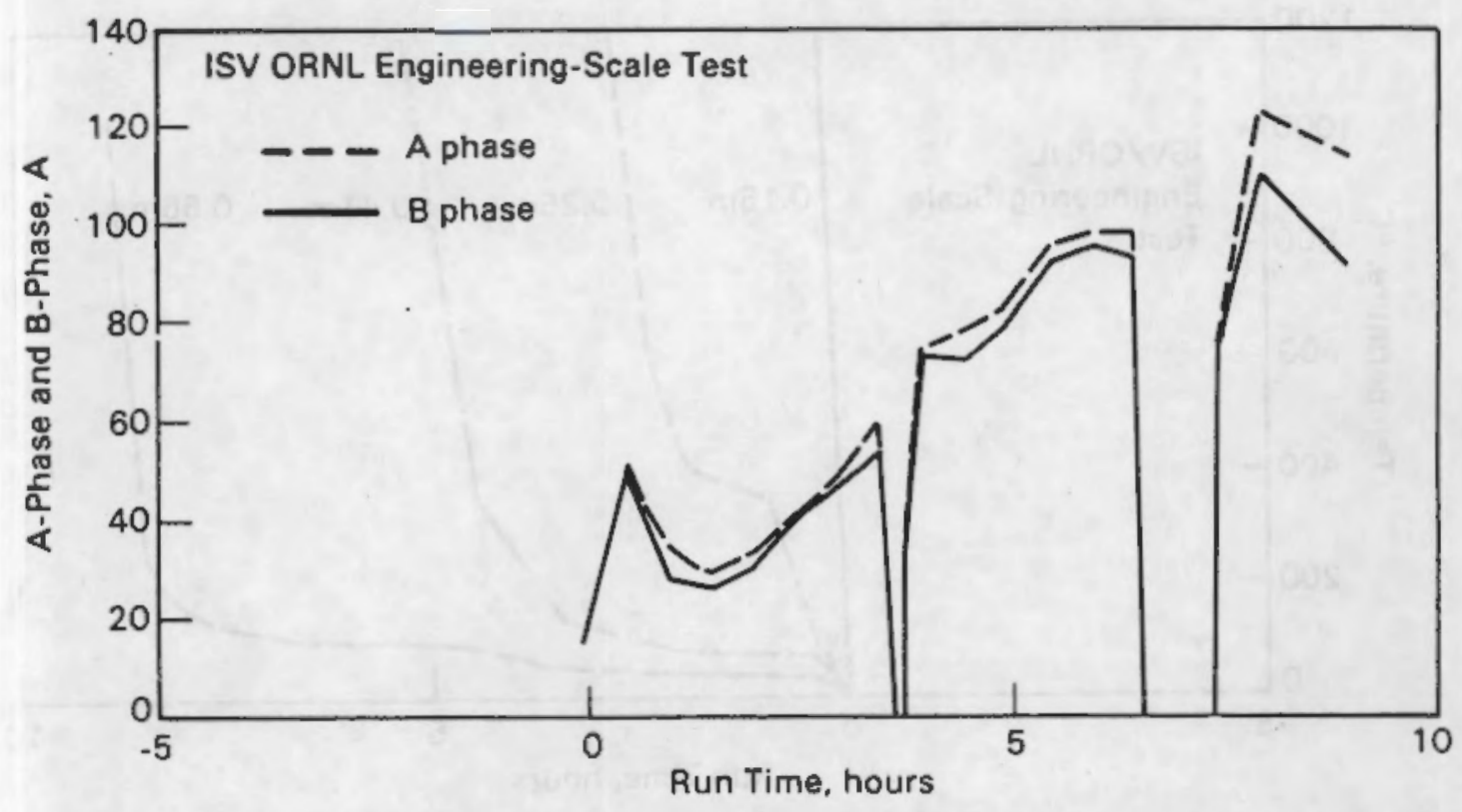

FIGURE 12. A-Phase and B-Phase Amps Versus Run Time

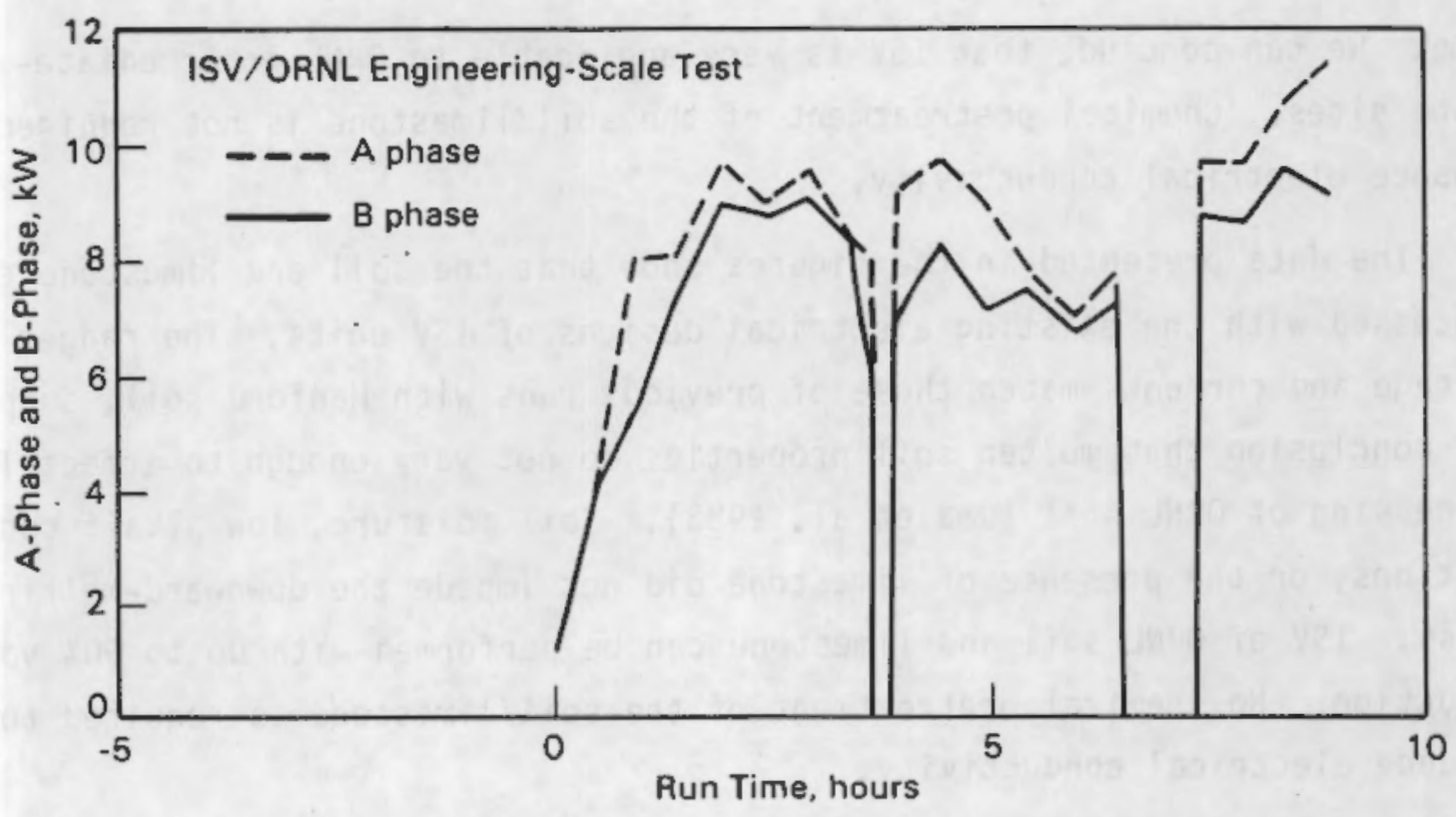

FIGURE 13. A-Phase and B-Phase Kilowatts Versus Run Time 


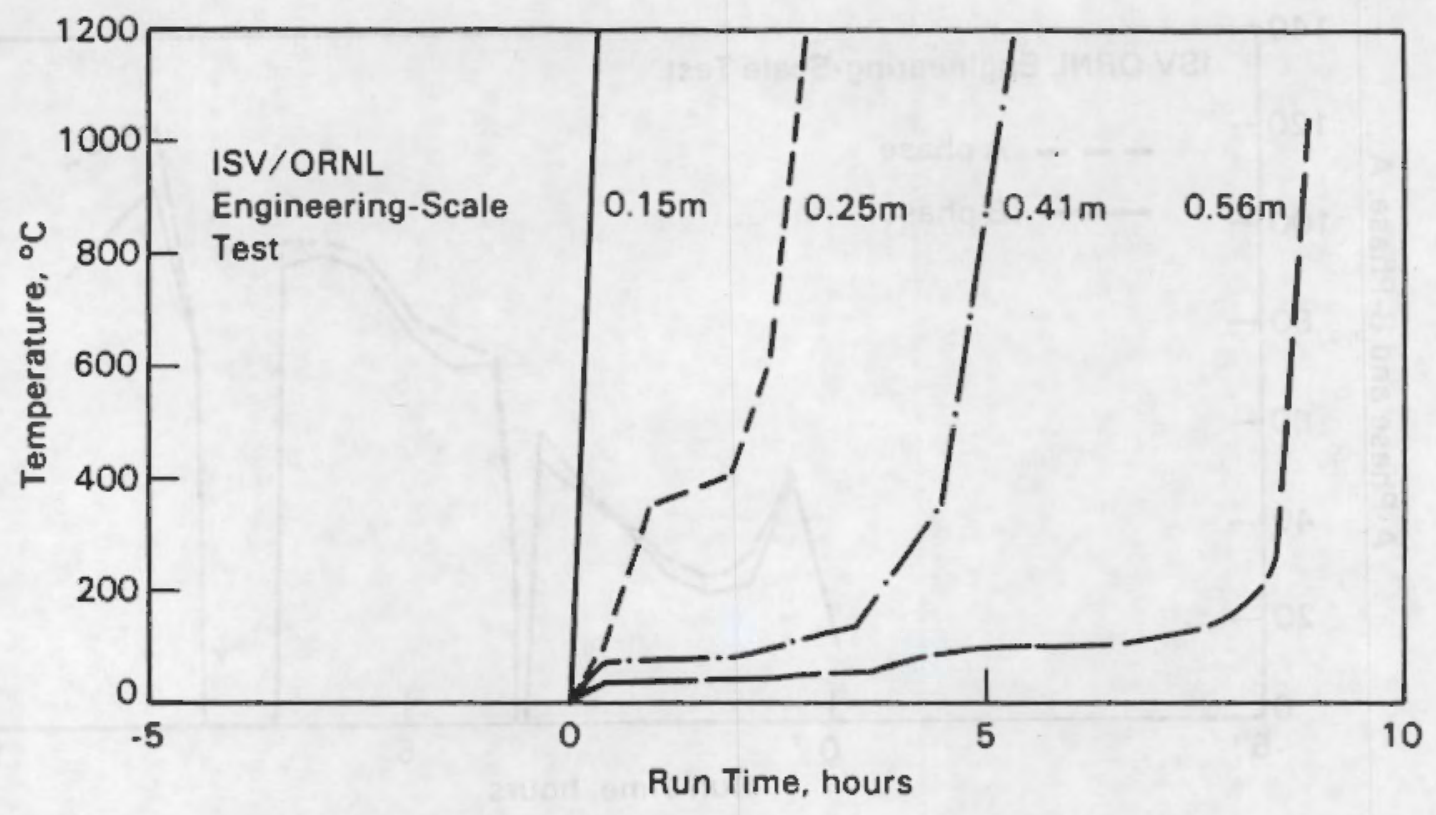

FIGURE 14. Temperature of the $0.15-, 0.25-, 0.41-$ and $0.56 \mathrm{~m}(6,10,16$, and 22 inch) Thermocouple Versus Run Time

time. We can conclude that ISV is very applicable to ORNL intermediate-level waste sites. Chemical pretreatment of the soil/limestone is not required to enhance electrical conductivity.

The data presented in the figures show that the soil and limestone can be processed with the existing electrical designs of ISV units. The ranges of voltage and currents inatch those of previous runs with Hanford soil, supporting the conclusion that molten soil properties do not vary enough to affect ISV processing of ORNL soil (Oma et al. 1983). Soil moisture, low alkali concentrations, or the presence of limestone did not impede the downward-melting progress. ISV of ORNL soil and limestone can be performed with up to $60 \%$ volume reduction. No chemical pretreatment of the soil/limestone is required to enhance electrical conductivity. 


\subsection{ENGINEERING-SCALE TEST RESULTS AND ANALYSIS}

Sampling was used to compile a material balance for the cesium and strontium retention. Samples were taken from HEPA filter media, each of the two water scrubbers, millipore sampler filters, samples of the surrounding soil of the vitrified mass, and core samples of the vitrified mass.

Off-yas stream sampling (Figure 15) provided an quantitative analysis of the amount of cesium and strontium released during processing. The off yas was sampled at a rate of 2.73 to $3.03 \mathrm{~L} / \mathrm{min}$ through the sample train to match offgas velocity at the isokinetic sampling port. During the processing period, seven liquid samples were taken from each of the liquid scrubbers and six millipore filter samples. The gas line to the sample train was flushed with water between each sequence of samples to detect line accumulation. Table 5 provides analytical results for the water scrubbers and the millipore filter. The second-stage water scrubber served as a final check of the first-stage scrubber efficiency. The millipore filter serves as a final check prior to atmosphere releases. Sample periods ranged from 1.08 to 3.58 hours.

The data from Table 5 were corrected for off-gas flow, sample time, and sampler system flow for conversion to grams released from the soil. The converted gram quantities collected in the off-gas system were divided into the amount of cesium and strontium placed in the soil prior to testing. This gives a mass to off-gas decontamination factor (DF) for cesium of $2.6 \times 10^{4}$ and a strontium DF of $2.7 \times 10^{4}$. With the data from Table 5, the calculated amount of cesium and strontium released to the off-gas system was plotted as shown in Figure 16. These data are confirmed by analysis of off-gas line HEPA filter samples.

Table 6 gives the chemical analysis of a single core sample taken from the engineering-scale test.

In reviewing the data in Table 6 , note that the strontium converts to a larger quantity than that placed in the test site prior to vitrification. It appears that the core sample was taken in an area where convection in the inelt 


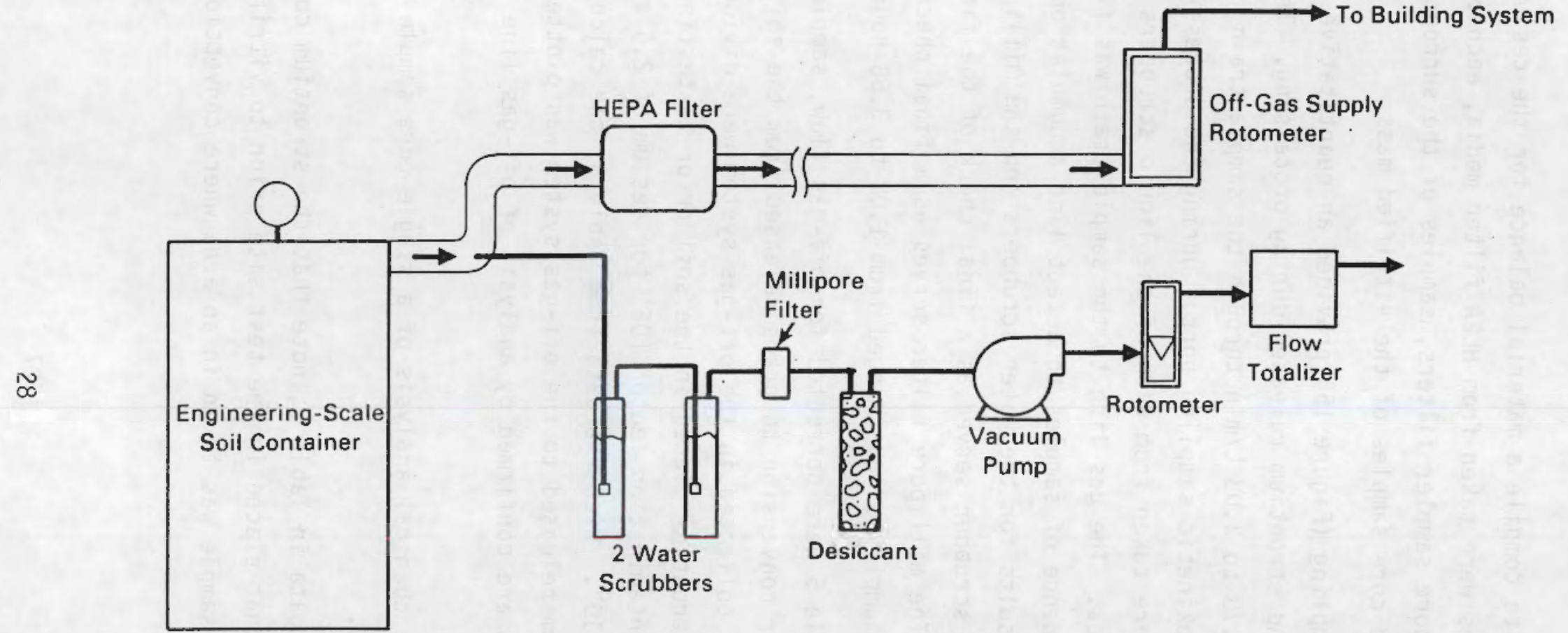

FIGURE 15. Off-Gas Sample System for Engineering-Scale Oak Ridge National Laboratory Test 
TABLE 5. Scrub System Sample Analyses ( $\mathrm{gg} /$ sample period)

\begin{tabular}{|c|c|c|}
\hline Samples & Cesium & Strontium \\
\hline $\begin{array}{l}\text { Scrubber } 1 \\
\text { Scrubber } 2 \\
\text { Flush } \\
\text { Millipore }\end{array}$ & $\begin{array}{l}<1.275 \\
<1.275 \\
<0.225 \\
<0.16\end{array}$ & $\begin{array}{l}21.5 \\
21.68 \\
4.37 \\
0.25\end{array}$ \\
\hline $\begin{array}{l}\text { Scrubber } 1 \\
\text { Scrubber } 2 \\
\text { Flush } \\
\text { Millipore }\end{array}$ & $\begin{array}{l}<1.275 \\
<1.275 \\
<0.33 \\
<0.16\end{array}$ & $\begin{array}{r}28.05 \\
21.93 \\
6.73 \\
0.25\end{array}$ \\
\hline $\begin{array}{l}\text { Scrubber } 1 \\
\text { Scrubber } 2 \\
\text { Flush } \\
\text { Millipore }\end{array}$ & $\begin{array}{c}<1.275 \\
<1.275 \\
0.560 \\
<0.16\end{array}$ & $\begin{array}{r}24.23 \\
21.68 \\
6.37 \\
0.25\end{array}$ \\
\hline $\begin{array}{l}\text { Scrubber } 1 \\
\text { Scrubber } 2 \\
\text { Flush } \\
\text { Millipore }\end{array}$ & $\begin{array}{r}4.77 \\
<1.30 \\
1.54 \\
<0.16\end{array}$ & $\begin{array}{r}25.71 \\
21.25 \\
6.37 \\
0.29\end{array}$ \\
\hline $\begin{array}{l}\text { Scrubber } 1 \\
\text { Scrubber } 2 \\
\text { Flush } \\
\text { Millipore }\end{array}$ & $\begin{array}{r}2.12 \\
<1.30 \\
1.54 \\
0.40\end{array}$ & $\begin{array}{r}24.91 \\
22.10 \\
3.70 \\
0.15\end{array}$ \\
\hline $\begin{array}{l}\text { Scrubber } 1 \\
\text { Scrubber } 2 \\
\text { Flush } \\
\text { Millipore }\end{array}$ & $\begin{array}{c}3.24 \\
<1.30 \\
0.585 \\
N R(a)\end{array}$ & $\begin{array}{r}22.14 \\
22.10 \\
3.15 \\
N R\end{array}$ \\
\hline $\begin{array}{l}\text { Scrubber } 1 \\
\text { Scrubber } 2 \\
\text { Flush } \\
\text { Millipore }\end{array}$ & $\begin{array}{l}67.5 \\
12.2 \\
30.5 \\
28.0\end{array}$ & $\begin{array}{r}21.50 \\
21.68 \\
4.60 \\
0.18\end{array}$ \\
\hline
\end{tabular}

(a) Filter was not removed during this sample period.

zone created a higher concentration of strontium than that distributed throughout the remaining block. Previous convection data from ISV testing shows distribution of radionuclides to be within a factor of three from the norm (Timmerman and Oma 1984). Core sample examination also reveals the final soil and limestone concentrations in the vitrified product are $68 \mathrm{wt} \%$ soil and 


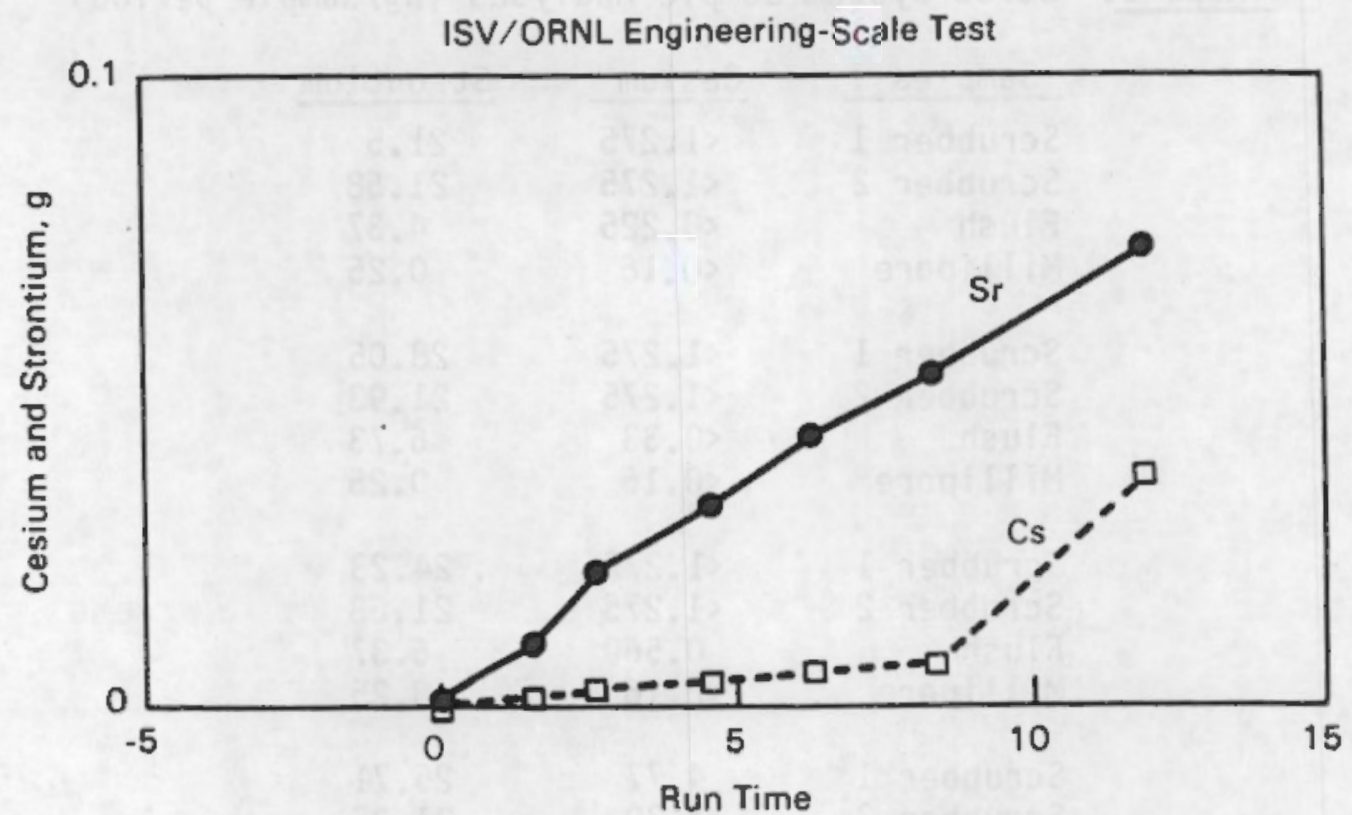

FIGURE 16. Projected Amount of Cesium and Strontium in Off-Gas System Based on Off-Gas System Sample Analysis

TABLE 6. Normalized Chemical Analysis of a Single Core Sample from Engineering-Scale Test

$\begin{array}{lr}\text { Element } & \text { wt\% } \\ \mathrm{Al}_{2} \mathrm{O}_{3} & 14.68 \\ \mathrm{~B}_{2} \mathrm{O}_{3} & 0.14 \\ \mathrm{BaO}^{2} & 0.10 \\ \mathrm{CaO} & 14.99 \\ \mathrm{Fe}_{2} \mathrm{O}_{3} & 4.14 \\ \mathrm{~K}_{2} \mathrm{O} & 2.28 \\ \mathrm{Li}_{2} \mathrm{O} & 0.07 \\ \mathrm{MgO} & 10.88 \\ \mathrm{MnO}_{2} & 0.14 \\ \mathrm{MoO}_{3} & 0.05 \\ \mathrm{Na}_{2} \mathrm{O} & 0.93 \\ \mathrm{SiO}_{2} & 45.41 \\ \mathrm{SrO}^{2} & 4.17 \\ \mathrm{TiO}_{2} & 0.64 \\ \mathrm{ZrO}_{2} & 0.03 \\ \mathrm{Cs}_{2} \mathrm{O}_{2} & 1.35 \\ \mathrm{Total}^{2} & 100.00\end{array}$


32 wt\% limestone. This is slightly higher in soil concentration than the laboratory-scale sample, which resulted in a 62 wt\% soil and $38 \%$ limestone concentration.

Samples of the soil surrounding the vitrified mass were taken at the top on two sides, midway down the vitrified mass on two sides, and under the vitrified mass in two locations. The bottom samples were collected after the mass was removed from the test assembly. All soil sample analyses showed a water leach analysis for cesium of $<0.001 \%$, indicating no outward migration of cesium during processing.

The concentration of cesium and strontium placed in the soil prior to vitrification testing were several orders of magnitude greater than that found in ORNL Trench 7. This increased concentration was used to provide detectable levels of cesium and strontium in the off-gas sampling system and detectable quantities for MCC-1 evaluation of the vitrified mass.

MCC-1 tests were performed on the engineering-scale vitrified mass. The tests were performed to determine product durability for the 68/32 engineeringscale soil and limestone and to verify the findings of the laboratory soil and limestone tests. One of two samples of the engineering-scale vitrified glass was heat-treated at the same cooling rate as the face of a full scale ISV monolith (Figure 5). Both samples taken directly from the engineering-scale vitrified mass were subject to a 28 -day, MCC -1 leaching test at $90^{\circ} \mathrm{C}$ in deionized water.

A summary of the results from these tests is presented in Figure 17 . The leaching releases were similar for both the engineering-scale samples and the laboratory tests discussed earlier in this report, except that the releases for cesium, potassium and strontium were significantly lower for the engineeringscale heat-treated and non-heat-treated glasses. The strontium releases reported for the engineering-scale test results are probably more accurate than those reported in the laboratory test results section. The concentration of strontium in the engineering-scale glasses was approximately 400 times yreater than in the laboratory-scale glasses (4 to 0.01 wt\%). 


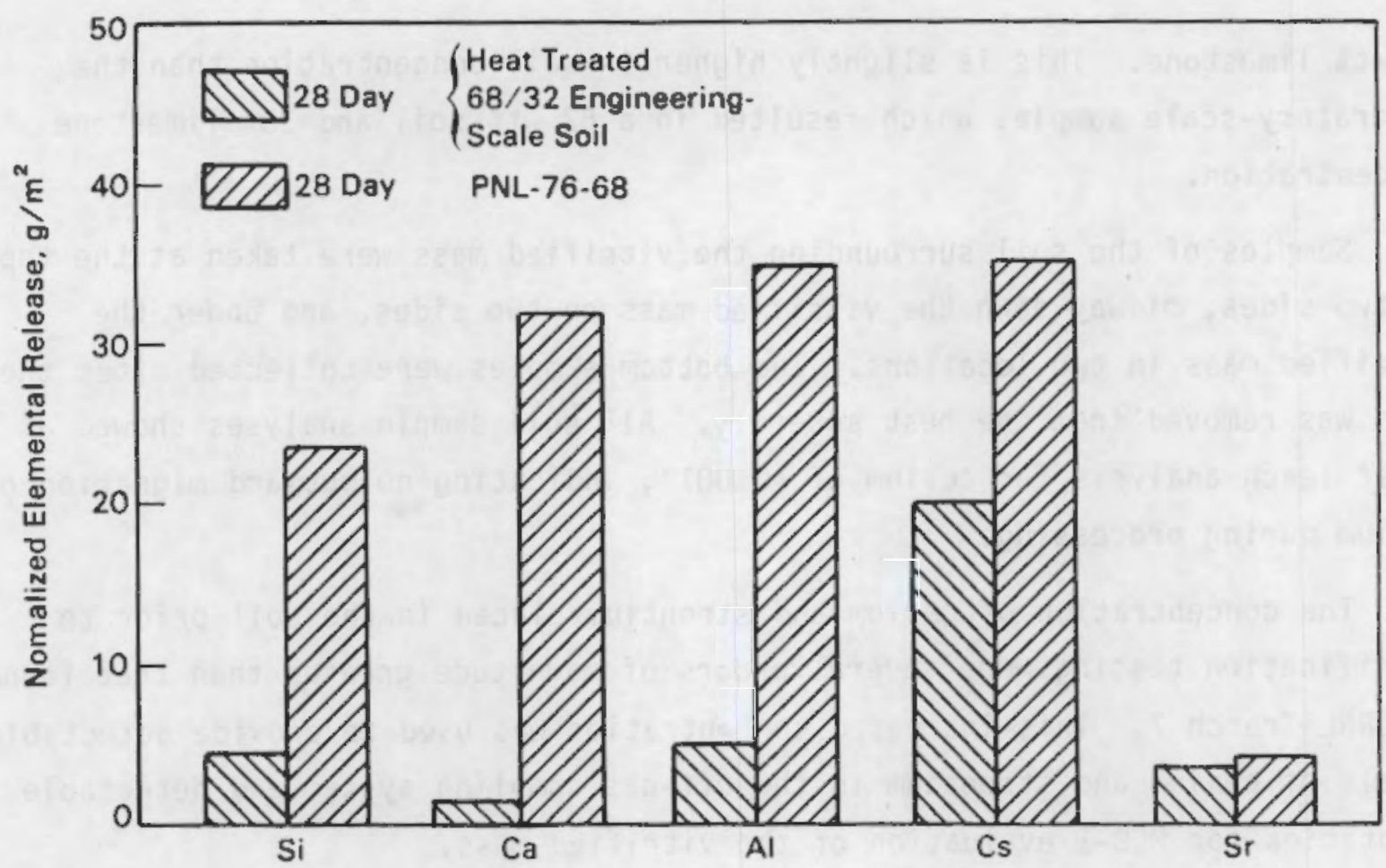

FIGURE 17. Heat-Treated $68 / 32$ Soil/Dolomite MCC-1 (Monolith) Test Results as Compared to PNL $76-68$ Glass

Because 0.01 wt\% of strontium in the laboratory test is near the detection limits of ICP analysis, the analytical numbers at 4 wt\% are well above the detection limits to improve the confidence level.

The most probable reason for the increased durability of the engineeringscale samples is the higher soil to limestone ratio. Since this ratio is more representative of the actual test condition, the engineering-scale data should be used to predict waste form durability of ISV applied to ORNL low level waste sites. Another possibility is that the engineering-scale sample was held at processing temperature for a longer time period resulting in more homogeneous vitrification and an approved waste form.

Comparison of the heat-treated $68 / 32$ engineering-scale soil to the PNL 76-68 for 28-day leach test are shown in Figure 18. Normalized strontium release from the $68 / 32$ soil/1imestone ISV product is the same as or less than the 76-68 glass. The normalized cesium release, for instance, is a factor of 3 lower than that of the $76-68$ glass. 


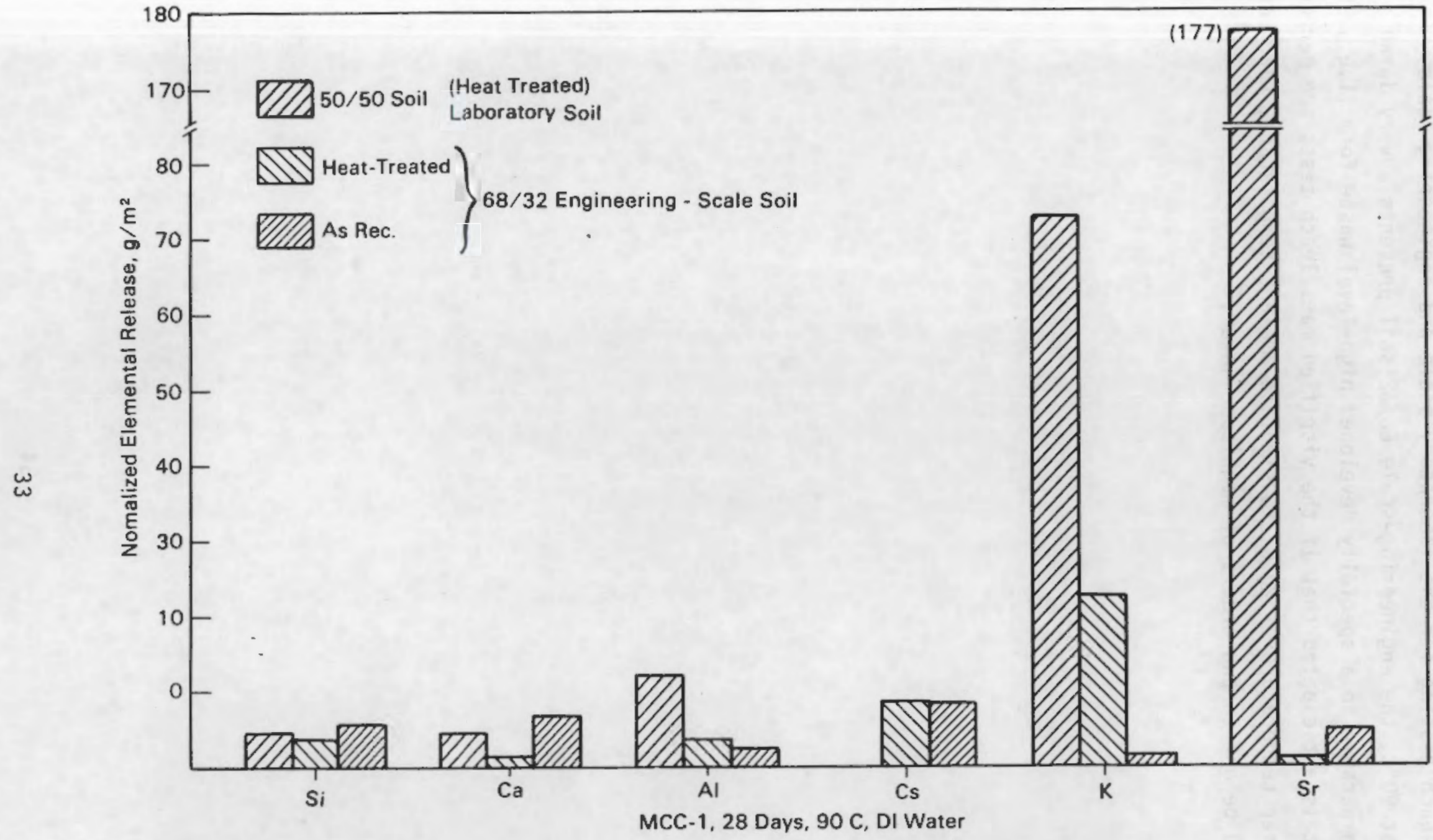

FIGURE 18. Comparison of Engineering-Scale Soil/Limestone to Laboratory-Scale Soil/Limestone 
With leach testing for the laboratory-scale and engineering-scale performed at $90^{\circ} \mathrm{C}$, the engineering-scale $68 / 32$ soil presents a very durable product, comparable to a specially developed high-level waste form (i.e., PNL 76-68). It is anticipated that if the vitrified mass leach tests are performed at the lesser temperature of $20^{\circ} \mathrm{C}$, to simulate ambient temperature, the leach rates would be one to two orders of magnitude lower. 


\subsection{REFERENCES}

Brouns, R. A, J, L. Buelt, and W. F. Bonner. i983. "In Situ Vitrification of Soil." U.S. Patent 4,376,498, March 1983.

Guelt, J. L., and J. G. Carter. 1986. Description and Capabilities of the Large-Scale In Situ Vittrification Process, PNL-5738, Pacific Northwest Laboratory, Rlchland, Washington.

Bueit, J. L* and 5 . T. Freim, 1996. Demonstration of In situ viteiflcation for volume Reduction of Zircontallime Sludges. Pacific Northwest Laboratory, Richland, Washington.

Buelt, J.L., C. C. Chamm, S. M. barnes, and R. 0. Dienks. 1979. "A Review of Continuous Ceranic-lined Melter and Associated Experience at PNL." pp. 107-113. In Cerantcs and Nuclear Waste Management. CONF-790420. Technical Infomation Genter, Springfield, Virginia.

Cnick, L. A. et al. 1984. West Valley High-Level Nuclear Waste buss Development: A Statistically Designed Mixture Study. PAL-4992, Pacitic Northwest laboratory, Richland, Washington.

Materials Characterization Center, Rev. 7, 1986, "McC-10 Static Leach Test Method." In Nuclear Waste Materials Handbook. Test Methods. DOE/TIC11400. Pacific Northwest Laboratory, Richland, Washington.

Materials Characterizat on Center, Rev. 7, 1986 , MCC-35 Agitated Powder Leach Test Method." In last Methods Subnitued for Nuclear Waste Materials Handbook. PNL-3990, Pacific Northwest Laboratory, Richland, Washington.

Oma, K. H, O. R. Brown, J, L, Buelt, W. Fitzatrick, K. A. hawley, 6. B. Mellinger, B. A. Napier, D. A. Solvoera, S. L. Stein, and 6. L. Timnerman. 1983. In situ Vitrification of Transuranic Vastes: Systens Evaluation and Applications Assessinent. PAl.4800, Pacific Northwest Laboratory, Richland, washington.

Timmerman, C. L., and K. H. Oma. 1984. An in Sizu Vitrification pilot-Scale Radioactive Test: PNL-5240, Pacifle Nofthwest Laboratory, Richland, Washington.

Timmerman, C. L., R. A. Brouns, J. L. Bueit, and K. H. Ona, 1983, "In Situ Vitriflcation: Pjlot-Scale Development. "Nuclear and Chentcal Waste Managenent. Vol. 4, No. 3, po. 267-275, Pergamon Press Inc.. Elmsford, New York. 
, 


\section{DISTREDTION}

No. of

Coples

OFFSITE

30 De Technical Information Center

3. W. Bernett, $R W-20$

Doe office of Civilian

Radioactive Uaste Managemant

Forrestal Buildang

Washington, DC 20585

C. R. Conley, Rum

DOE office of Clvilian

Radioactive vaste Managenent

Forrestal Builiting

vashington, of 20585

M. W. Fres

Ceologic Repository Division

DoE office of Civilian

fangactive Waste Management

Forrestal Building

vashington, DC 20585

R. Stein, Rh-23

DOE Office of Civilian

Ratloactive Waste Manegement

Forrestai Buitaing

Washington, oc 20585

D. B. LeClatre, $P_{-12}$

DOE Office of Defense baste Byprodict Management.

GTN

Washington, 0.t. 20545

R. D. Walton, Ir, op-lzz

DOE Office of ligfense waste GTH

Gyprofuets Managenent

Wastington, D.C. 20545
No. of

Copies

3. Jucha do -123

DoE Offlee af Defense Haste

Ryproducts Management GTN

Washingen, 0.C. 20545

J. E. Baublitz, AF-24

DoE office of Terminal Waste

Disoosal Remetial Action

GTH

Washington, DC 20545

J. A, Coleman, $\mathrm{NE}-25$

Doe office of Terminal haste

Disposal Remedial Action GTN

Washington, OC 20545

0. 1. Megof , ME -23

DoE 0ffice of Terninal vaste

Uisposal Remedial Action G)

Washington, oc 20545

J. A. Turi, AE-2b

Dot iffice of Terminal laste

Disposal Renedial Action GTV

Vashington, OC 20545

W. R. Voigt, NE-20

DoE Office of Termitial haste

Disposal \& Remedial Acton GTH

Vashington, DC 20545

H. F. Walter, $\mathrm{NE}-2 \mathrm{~s}$

DOE office of Teminal Waste

Disposal Remedial hction GT:

Washington, oc 20545 
No. of

Coples

J. $\mathrm{B}, \mathrm{Zarn}, \mathrm{NE}-25$

DoE uffice of Terminal Waste GTh

Disposal Renedial Action

Washington, De 20545

M. J. Bell

Division of Nuclear Materials Safety Safeguards

Mail Station 881-5S

Nuclear Regulatory Comisiston

washington, OC 20555

A. T. Clark
Division of Fuel Material
Safety

Nuclear Regulatory Commisston

Wastington, oC 20555

W. J. Diroks

difice of the Executive

Director for operations

Mali Station 6209

Nuclear Regulatory Commission

washington, DC 20555

0. Egan

Environmental Protection Agency Office of Radiation Programs

401 M Street, S.W.

washington. OC 20450

G, L. Sjoblom

Environmental Protection Agency

Office of Radiation Prograns

401 M Street, S.W.

Washington, oc 20460

M* McF adden

DOE Albuquerade Operatana Orfice

P.0. Box 5400

Albuquerque, Nat 87185
No. of

Coptes

J. McGough

DOE Albuquerque Operations

office

P.0. box 5400

Albuquerque, NM 37165

H. H. Hannum

DOE west Valley operations

Office

P.0. Box 191

West valley, NY 1417"

J. P. Hamric

DoE Idaho Operations office

550 Second Street

Idaho Falls, ID d3401

J. B. Whitsett

DOE Idaho Operations of lice

550 Second street

ldaho Falls, 10 8340

L. Lenni

DoE San Francisco operations

1333 Broandw

San Franciseo. CA 94612

W. E. Pasko

WUE Jak Ritge Operations office

$9.0 .80 \times E$

oak Ridge, TN 37830

S. A. Mann

DoE Chicago Operations office

9600 South Cass Avenue

Argonne, IL 60439

1. 0. Neff

DOE National Waste Progran

Office

505 King Avenue

Columbus, 애 43201 
No. of

Copies

G. X. Dertel

DOE Savannah River Orerations

Dffice

P.0. Box A

Aiken, SE 29801

D. L. Weth

Oof Nevata Operations Offlca

P.e. Pox 19100

Las Vegas, MV 89114

C. 5. Abrams/j. H. Kittel

Argonne National Laboratory

970 il South cass Avenue

Argonne, li botsy

M. J. Steindier/L. E. Trevorrow Argonne lational Laboratory

inu south Cass Avente

argonne, It 60439

W. J. Madia

Batel le Menorial Institute

office of crystalline

Repository Development

980 South Cass Avenue

Argonne, IL 50439

W. A. Carbeiner/S. H. Bashan

Gattelle Menorial Inttitute

Project Management Djulsion

Sus King Avenise.

Columbus, OH 43201

J. F. Xitrcher

Rattelle Memorial inctitute

Project Managenent biviston

Sus king tuenue

colunbis, on 43201

Technica? Library

Battelle Memorial Instutute

project Management nivision

sus king Avenue

Columbus, 0H
No. of

Coples

\author{
L. D. Ranspote \\ Lawrence Livermore Nationa \\ Laboratory $L / 240$ \\ University of California \\ P.0. Box 808 \\ Livermore, CA 945513 \\ 0. T. 0akley, 19671 \\ Los Alamos celentific \\ Laboratary \\ P.i. Pox 1663 \\ Los Alamos. HM 87544 \\ T. H. Row \\ Odo Pitge Hationa latoratory \\ P. P. Pox $x$ \\ Oak Ritge, T! 37330 \\ J. 0. Bloneke \\ Oak Rilge vational Laboratory \\ P.O. Bo. \\ bak Ritge, Th 37830 \\ W. D. Bitarch \\ Oak Pidge National Laboratory \\ P. O. Box Y \\ wax Ritge, TN 37 wat $^{2}$ \\ N. J. Cutshall \\ Oak \\ P.o. pox \\ OAk pitge, Th 37830 \\ L. An nole \\ Gak Rifge vational Laboratory \\ P.D. Eor y \\ Dak Ritge, TN 3783 t \\ 10 R. P. Spalding \\ Oak Rifge tatimal Lahoratory \\ P.O. $\mathrm{pox}$ स \\ oak Rlone, TH 37030 \\ 0. R. Anderson \\ Santia Lahoratories \\ p.0. $36 x 5300$ \\ Alhuquerque, him 37185
}


No. of

Copies

J. F. Ney

Sandia Laboratories

P.0. Box 5800

Albuquerque, NM 87185

R. W. Lynch

Sandia Laboratories

P.0. Box 5800

Albuquerque, NM 87185

W. Weart

Sandia Laboratories

P.0. Box 5800

Albuquerque, NM 87185

Technical Library

Sandia Laboratories

P.0. Box 5800

Aibuquerque, NM 87185

B. R. Wheeler

West inghouse Idaho Nuclear Co., Inc.

P.0. Box 4000

Idaho Falis, ID 83401

M. D. Boersina

E. I. du Pont de Nemours Company

Savannah River Laboratory

Aiken, SC 29801

J. L. Cranda11

E. I. du Pont de Nemours Company

Savannah River Laboratory

Aiken, SC 29801

E. J. Hennelly

E. I. du Pont de Nemours Company

Savannah River Laboratory

Aiken, SC 29801
No. of

Copies

L. L. Kilpatrick/L. M. Lee

E. I. du Pont de Nemours Company

Savannah River Laboratory

Aiken, SC 29801

S. Mirshak

E. I. du Pont de Nemours Company

Savannah River Laboratory

Aiken, SC 29801

R. M. Wallace

E. I. du Pont de Nemours Company

Savannah River Laboratory

Aiken, SC 29801

E. A. Jennrich

EG\&G Idaño

P.0. Box 1625

Idaho Falls, ID 83415

K. V. Gilbert/P. G. Hagan

Rockwell International

Rocky Flats Plant

P.0. Box 464

Golden, CO 80401

G. W. Meyers

Atomics International Division

Rockwell Internationa 1

8900 DeSoto Avenue

Canoga Park, CA 91304

T. H. Pigford

Department of Nuclear

Engineering

University of California

Berkeley, CA 94720

M. E. Spaeth

Science Applications, Inc.

2769 South Highland

Las Vegas, NV 89109 
No. of

copies

J. F. Strah

Weston

2301 Research Boulevard

Thite Floor

Rocktille, MD 20850

R. Willians

Electric Power Research

Institute

3412 Hill vien Avenue

P.0. Box 10412

palo Alto, CA 94304

C. C. Chapman

west valley nuclear services company

P.0. Box 191

West Valley, NY 14171

J. C. Cwynar

West Valley Muclear Services Company

P.0. Box 191

West Valley, N 14171

1. R. Elsenstate

West Valley Nuclear Services

Company

P.0. Box 191

West valley, NY 14171

U. L. Knabenschuh

West Valley Nuclear Services company

P. O. Box 191

West Valley, NY 14171

J. E. Krauss

West Valley Nuclear Services

Company

P.0. Box 291

west Valley, Ny 1417

J. N. Pope

West Valley Huclear Services Company

9.0. Box 191

West valley, Ny 14171
No. of

Copies

J. W. Bartlett

The Analytic Sciences

Corporation

6 Jacob vay

Reading, MA 01867

W. A. Freeby/J, L. Jardine

Bechtel National, Inc.

P.0. Box 3965

San Francisco, CA 94119

Librartan

Westinghouse Eectric Corporation

Technicat Library

P.0. $30 \times 40039$

Albuquerque, M 87196

L. L. Hench

Department of Materials Science Engineering

University of Flarida

Gainesville, PL 32611

1. L. Larocea, Chairman

Energy Research \& Development Authority

Empire State plaza

Albany, NY 12223

R. G. Post

College of Engineering

University of Arizona

Tucsor, Az 85721

K. Mckinley

Joint Integration office

Rockwell Hanford operations

$30 \times 3150$

Albuguergue, Na 37190

M. Neal

Jofnt Integration office

Rockelel Hanford Operations

Box 3150

Albuquerque, he 87190 
ONSITE

8 DOE Richland Operations Dffice

J. H. Anttonen

E. A. Bracken

P. A. Craig

M. T. Karagianos

J. L. Rhoades

M. W. Shupe

J. J. Sutey

J. D. White

14 Rockwell Hanford Dperations

B. N. Anderson

L. Fitch

K. A. Gasper

R. N. Gurley

N. W. Kirch

H. E. McGuire

D. E. McKinney

J. W. Patterson

R. D. Prosser

J. H. Roecker

T. B. Venziano

D. D. Wodrich

R. J. Wojtasak

File Copy

7 UNC United Nuclear Industies

T. E. Dabrowski/W. J. Kyriazis

2 Westinghouse Hanford Company

R. E. Lerch

J. D. Watrous
No. of

Copies

45 Pacific Northwest Laboratory

S. 0. Bates

W. F. Bonner

J. L. Buelt

H. C. Burkholder

J. R. Carrell

J. G. Carter (10)

D. B. Cearlock/R. P. Marshall/

W. R. Wiley

T. D. Chikalla

V. F. FitzPatrick

D. L. Futch

J. E. Hansen

M. S. Hanson

J. H. Jarrett

D. E. Knowlton

L. T. Lakey/K. M. Harmon

J. M. Latkovich

R. C. Liikala

G. D. Maupin

J. L. MCElroy

J. E. Minor

I. C. Nelson/J. G. Stephan

K. H. Oma

A. M. Platt/R. E. Nightingale

J. M. Rusin

J. A. Shaw

D. J. Silviera

S. L. Stein

C. L. Timmerman

Technical Report files (5)

Publishing Coordination (2) 